\title{
ARTE Y LITERATURA DEL LITORAL. LOS PROYECTOS EDITORIALES DE MONTES I BRADLEY
}

Art and Literature of the Littoral. Montes i Bradley's Editorial Projects

\author{
Elisabet Veliscek, Centro de Investigaciones de Arte Argentino \\ y Latinoamericano, Universidad Nacional de Rosario, \\ Consejo Nacional de Investigaciones Científicas y Técnicas de Argentina. \\ Correo electrónico: elisabet-veliscek@hotmail.com
}

Recepción: 24/05/2020

Aceptación: 27/10/2020

Resumen: El texto aborda el análisis de algunos proyectos editoriales dirigidos por Ricardo Ernesto Montes i Bradley (1905-1976) durante el transcurso de los años treinta y cuarenta en la ciudad de Rosario, Argentina. Se trata de una serie de publicaciones periódicas en donde tenían lugar los últimos debates del momento, se difundían textos de escritores regionales y circulaban a través de noticias o imágenes las nuevas tendencias estéticas. A partir de la importancia que tuvieron esas publicaciones en el entramado cultural de la época, se indagan los intercambios trazados por el escritor con los artistas plásticos, periodistas, críticos e intelectuales que colaboraron en las revistas y boletines editados por él, teniendo en cuenta, particularmente, de qué manera se inscribe la intervención del pintor Ricardo Warecki (19111992) en ese circuito y cuáles son las características que adquiere su obra en ese contexto.

Palabras clave: arte moderno, publicaciones periódicas, cultura impresa.

\begin{abstract}
The text addresses the analysis of some publishing ventures directed by Ricardo Ernesto Montes i Bradley (1905-1976) during the course of the 1930s and 1940s in the city of Rosario (Argentina). It is a series of periodicals where the last debates of the moment took place, texts by regional writers were disseminated and new aesthetic trends circulated through news or images. From the importance that these publications had in the cultural framework of the time, we investigated the exchanges traced by the writer with the artists, journalists, critics and intellectuals who collaborated in the magazines and bulletins published by him, taking into account, particularly, in what way the intervention of the painter Ricardo Warecki (1911-1992) is inscribed in this circuit and what are the characteristics that his work acquires in that context.
\end{abstract}

Keywords: modern art, periodicals, printed culture. 


\section{Itinerarios y personajes}

Durante los años treinta y cuarenta el artista Ricardo Warecki (Rosario, 1911-1992) sostuvo una amistad estrecha con el escritor Ricardo Ernesto Montes i Bradley (Rosario, 1905Buenos Aires, 1976) que se tradujo en una colaboración asidua en sus diversos proyectos editoriales dedicados a divulgar la obra literaria de autores, en gran medida, pertenecientes a la Región del Litoral, y a difundir la creación plástica de artistas locales y nacionales a través de estudios críticos e imágenes. Se trataba de una serie de libros y revistas donde tenían lugar los últimos debates, se difundían textos afines a las corrientes literarias del momento y circulaban a través de noticias o imágenes las nuevas tendencias estéticas. A partir de la importancia que tuvieron esas publicaciones en el entramado cultural de la época, se indagan aquí los intercambios trazados por el escritor con los artistas plásticos, periodistas, críticos e intelectuales que colaboraron en los volúmenes por él editados, teniendo en cuenta, particularmente, de qué manera se inscribe la intervención del pintor Ricardo Warecki en ese circuito y cuáles son las características que adquiere su obra en ese contexto.

El diálogo entre literatura y artes plásticas caracterizó gran parte de las producciones culturales realizadas en Rosario durante, al menos, la primera mitad del siglo XX, impregnando también los programas editoriales de Montes i Bradley, como el Boletín de Cultura Intelectual y la revista Paraná. Si bien ambas publicaciones tenían una orientación vinculada a las artes y las letras modernas, se diferenciaban a partir de las características de su materialidad y el contenido de sus propuestas. A través de ensayos críticos que reflexionaban sobre episodios de la vida cultural, el Boletín hizo visibles las principales tensiones que atravesaban el campo artístico y literario de finales de los años treinta y el segundo tramo de los cuarenta, en un contexto convulsionado por redefiniciones e intervenciones institucionales, conflictos ideológicos y situaciones políticas adversas. La enunciación periodística que caracterizaba a los textos de Boletín se unía a una materialidad efímera y un tamaño grande en forma de pliegos, más cercano al diario, pero con una calidad de impresión superior y una mínima cantidad de páginas que le permitieron mantener una distribución mensual gratuita, por canje o solicitud directa, a través de la cual su director pudo consolidar una red de vínculos intelectuales sostenida mediante el intercambio epistolar. ${ }^{1}$

\footnotetext{
${ }^{1}$ Los boletines eran enviados por Montes i Bradley a distintas partes del mundo mediante el correo postal. A pesar de que la mayoría de sus papeles privados se han perdido, el Archivo Histórico Municipal de Río Cuarto
} 
El comentario informativo de Boletín y su confección abigarrada contrastaban, sin embargo, con la apariencia más austera de la revista Paraná, concebida como un objeto material para la perdurabilidad y el disfrute, presentada a partir de gruesos volúmenes encuadernados a la manera de un libro por entregas. Esa dimensión visual era reforzada desde sus páginas impresas sobre papel obra de alto gramaje, tapas de cartulina paño y reproducciones a color por fuera del texto junto con pequeñas viñetas realizadas a pluma, dibujos a lápiz, aguadas, témperas y fotografías fijadas al papel mediante las técnicas del fotograbado, la citocromía o grabados al linóleo estampados directamente del taco original. Las ilustraciones acompañaban mayormente la difusión de textos de ficción literaria y poética, semblanzas de escritores o personajes históricos, la divulgación de la historia de vida y la producción visual de artistas locales, así como algunas pequeñas notas de actualidad y reseñas de libros, con una estética pulcra más deudora de ciertas publicaciones literarias. A su vez, algunos de los dibujos eran elaborados por los mismos escritores para ilustrar sus fichas biográficas y textos cortos mientras que otros eran realizados en mayor medida por artistas regionales y locales.

En relación a las artes visuales, tanto el reservorio de textos privados de Montes i Bradley como los programas editoriales dejan entrever una sensibilidad estética que le movilizaba a buscar todos los medios posibles para adquirir, coleccionar y difundir la obra de los artistas plásticos y propagar las producciones literarias propias y ajenas en una ciudad que consideraba en gran medida hostil al desarrollo de las manifestaciones culturales. Para ello, Montes i Bradley utilizaba los recursos económicos que brindaba una ocupación multifacética dedicada a las ciencias jurídicas, el periodismo, la docencia y la literatura. Incluso su altruismo le llevó en ocasiones a desprenderse de obras de su pinacoteca para fomentar la creación de colecciones públicas, intentar auxiliar económicamente a algún artista de su círculo o animar a otros a que así lo hicieran. En sus escritos se puede advertir la preferencia por determinados artistas plásticos y, en especial, por los grabados de Juan Berlengieri y Sergio Sergi, pero también por todos aquellos a quienes intentó difundir a partir

se encargó de compilar las cartas de Montes i Bradley preservadas en la colección documental del escritor cordobés Juan Filloy, lo que nos permite suponer que el escritor rosarino poseía una abultada correspondencia con diferentes intelectuales y figuras de la cultura, incluso más allá de la Argentina. Algunos de los sobres encontrados con direcciones postales internacionales, a donde iban dirigidos los ejemplares del Boletín de Cultura Intelectual, y el conocimiento del escritor de varios idiomas, refuerzan esa hipótesis. Las cartas pueden consultarse en Eduardo Montes-Bradley (Ed.), El amigo de Filloy. Cartas de R-E Montes i Bradley a Juan Filloy (1935-1976) (Charlottesville: HTP Press, 2016). 
de sus artículos en las primeras páginas de cada nueva entrega de Boletín. Allí Montes i Bradley no sólo dio a conocer la obra de los artistas de un modo inusual en un momento donde la crítica local solía, con bastante asiduidad, defenestrar los envíos a los salones, sino también pudo expresar con libertad sus ideas estéticas y opiniones sobre el desempeño de algunas instituciones culturales de la ciudad. En ocasiones, las duras críticas hacia la gestión desarrollada por la Dirección Municipal de Cultura y el Museo Municipal de Bellas Artes "Juan B. Castagnino" al que tildaba de "mediocre", junto a los comentarios laudatorios dirigidos a ciertas figuras conocidas por su conservadurismo o el ataque hacia lo que llamaba los "adefesios" de la arquitectura moderna, empañaron un itinerario vinculado en gran medida a la preservación de los valores democráticos, delineando un trazado mucho más complejo sobre su pensamiento y accionar político. Indudablemente, algunas de las observaciones volcadas en Boletín parecían discrepar con su mirada reformista manifestada en el distanciamiento de la Iglesia y el posicionamiento crítico con respecto al disciplinamiento militar, a las que se sumaron sus diferencias insalvables con el peronismo, que le llevaron, a principios de los años cincuenta, a exiliarse en México, donde permaneció durante más de dos décadas antes de regresar a Argentina unos años antes de morir. Aunque, por lo general, el escritor no se dispensara públicamente en los medios sobre cuestiones relativas a la política nacional, estas impresiones podían quedar fijadas en sus documentos personales. En una de las cartas dirigidas a Juan Filloy — fechada a principios de agosto de 1952, dos años después de haberse establecido en México- se refería con angustia a la situación de la Argentina.

Sobre el tema Argentina, mucho podríamos escribir i leer respectivamente. Sin embargo, tengo hecho el firme propósito de no disgustarme por las cosas que más debieran apenarme, i como de tiempo en tiempo, algo sucede que lo consuela a uno, i se abren con interrogantes, caminos de ensoñación venturosa, resulta a la postre que aunque todo lo patrio hiere il cuore, la esperanza, la esperanza, la esperanza, lo reanima. I nos decimos: ¡ojalá! que reviente la primavera con áureas i cohetes que nos llenen el pecho de bienestar por el bienestar anhelado para el país que es nuestra cuna i será nuestra sepultura.

Volveremos entonces allá, cuando aquí terminemos de saber qué cosa es México. I ello será aunque amigos cordiales que bien nos quieren e inmerecidamente nos consideran, hacen lo posible por obtener nuestro consentimiento para obtenernos cátedra universitaria, i cargos de importancia, que bien alcanzarían a redondear la cantidad básica para poder vivir en este suelo, cuya vida, sincera i realmente me encanta pero... cuesta! ${ }^{2}$

\footnotetext{
${ }_{2}^{2}$ Ibid., 160-161. Debido a que las notas de Ricardo Ernesto Montes i Bradley no presentan ningún problema de comprensión, se prescindirá del 'sic' dejando las palabras tal como él las escribió.
} 
A pesar de la nostalgia que en distintos momentos decía sentir por su país, durante los años cincuenta y sesenta se vinculó con los artistas plásticos del muralismo mexicano, con importantes escritores locales y con otros intelectuales argentinos exiliados, formando rápidamente un entramado de sociabilidad cultural, aunque mantuvo viejas amistades por correspondencia. La habilidad del escritor en el desarrollo y sostenimiento de relaciones interpersonales con distintas figuras del escenario le permitió generar una red de intercambios que operó en un sentido estratégico para obtener mayor visibilidad y perpetuar una imagen de intelectual y animador cultural a nivel transnacional, a pesar de las divergencias que mostraba con ciertas instituciones de la ciudad que a su criterio habían sido absorbidas por los intereses privados de personas más vinculadas a la alta burguesía rosarina que al ambiente de la cultura.

Aunque prácticamente no se han conservado documentos que puedan atestiguar los intercambios epistolares de Ricardo Warecki con los artistas y escritores de su tiempo, algunos pequeños registros e indicios en los diarios y publicaciones periódicas nos permiten entrever una trayectoria muy importante dedicada en mayor medida a las artes gráficas, que incluía entre otras cosas, la elaboración de portadas de libros, ilustraciones de ficciones literarias y publicidades. En este sentido, la amistad que lo unía a diferentes escritores y ensayistas como R. E. Montes i Bradley, Félix Molina Téllez, José E. Peire y César Tiempo, por mencionar sólo algunos, se puede reconstruir, aunque de manera incompleta, como si se tratara de un rompecabezas del que se han perdido varias piezas fundamentales. Sin embargo, como plantea François Dosse,

La biografía puede ser una manera privilegiada de empezar a restituir una época con sus sueños y sus angustias. Walter Benjamín concebía al historiador como alguien que tenía que proceder a una reconstrucción de la continuidad de una época para distinguir en ella una vida individual con el fin de "hacer ver cómo la vida entera de un individuo está presente en una de sus obras, en uno de sus hechos $[\mathrm{y}]$ cómo en esa vida está presente una época entera". ${ }^{3}$

De la misma manera, las huellas discontinuas, por muy insignificantes que parezcan, muchas veces pueden ser más relevantes que los datos precisos para vincular intuiciones y completar vacíos documentales.

\footnotetext{
${ }^{3}$ François Dosse, El arte de la biografía: entre historia y ficción (México: Universidad Iberoamericana, 2007), 15.
} 
En este sentido, la amistad del escritor con Ricardo Warecki se puede trazar a partir de la colaboración del pintor en los diversos programas editoriales, así como en la reproducción de algunas fotografías de Boletín que captaron sus encuentros. En ese recorrido también queda en evidencia la proximidad de Montes i Bradley con Leónidas Gambartes, Juan Berlengieri, Santiago Minturn Zerva, los hermanos Guillermo y Godofredo Paino, Alfredo y Ángel Guido, Manuel Suero y con otros tantos creadores de la ciudad y del país, a quienes intentó favorecer mediante la promoción y circulación de sus trabajos. Por ejemplo, en 1937 intercedió en la donación de 18 obras de artistas santafesinos, en su mayor parte xilografías, para el Museo Municipal de Bellas Artes de Río Cuarto, al año siguiente gestionó la compra, por parte de Filloy para el mismo museo, de un autorretrato de Juan Berlengieri que había obtenido un premio estímulo en el XIV Salón de Otoño de Rosario, y en 1939 hizo posible la donación de obras de Leónidas Gambartes y Lino Enea Spilimbergo. ${ }^{4}$

Entre tanto, en sus palabras a Filloy menciona la promesa que hizo Alfredo Guido de obsequiar algunos aguafuertes al museo y también le asegura enviar unas láminas de Juan Berlengieri que mandó a imprimir al taller de la escultora y grabadora María Carmen Portela, en Buenos Aires, así como estampas de Rodolfo Castagna, Hemilce Saforcada, Lino Spilimbergo, Sergio Sergi, Clement Moreau, del uruguayo Carlos Alberto Castellanos y muchísimos otros artistas. La predilección de Montes i Bradley por el grabado y la gráfica en general queda demostrada por la manera en la que se refería a la destreza de algunos de estos creadores y la enorme cantidad que estampas que intentó hacer llegar al museo de Río Cuarto, al que estaba unido por lazos afectivos con su director. A su vez, también puede percibirse ese interés en el gran número de grabados, viñetas e ilustraciones que les encarga a los artistas —o que en ocasiones el mismo elabora- para acompañar los textos de los boletines, revistas y libros editados durante las décadas del treinta y del cuarenta en la ciudad de Rosario. Entre las distintas intervenciones plásticas se destacan, por su cantidad, las publicidades e ilustraciones diseñadas por Ricardo Warecki para el Boletín de Cultura Intelectual y la revista Paraná, así como los dibujos y exlibris realizados para el libro de

\footnotetext{
${ }^{4}$ Martina Guevara, "La construcción de un centro cultural desde la periferia: Juan Filloy y el Museo de Bellas Artes de Río Cuarto", Corpus. Archivos virtuales de la alteridad americana, vol. 8, núm. 1 (enero-junio de 2018): 1-22. https://doi.org/10.4000/corpusarchivos.2107. La autora hace referencia a las donaciones de Montes i Bradley que aparecen asentadas en los libros de actas de la institución. También menciona la entrega de un óleo de Manuel Musto por parte de la Comisión Municipal de Cultura de Rosario en 1941.
} 
poemas Alabado sea tu nombre y el ensayo biográfico titulado Resurrección de Lenzoni, publicados por Montes i Bradley en 1944 y 1945, respectivamente (figuras 1 y 2). ${ }^{5}$

\section{Ahora, las estrellas}

El Boletín de Cultura Intelectual editó 24 ejemplares durante su primera etapa comprendida entre junio de 1938 y octubre de 1943, y otros cinco números entre enero de 1944 y septiembre de 1947. La edición fue suspendida en distintos momentos, aunque inicialmente tuvo una periodicidad mensual que no pudo sostener en el segundo tramo de la publicación. Desde noviembre de 1938, y a lo largo del primer ciclo, cada nueva entrega llevó consecutivamente los nombres de los signos del Zodíaco junto a pequeños dibujos de Leónidas Gambartes realizados en una o dos tintas. ${ }^{6}$ Entre los artistas que participaron con viñetas e ilustraciones, Ricardo Warecki se encargó de diseñar el emblema que identificaría a la publicación: una mujer de apariencia clásica con el torso desnudo en alusión a las divinidades griegas y latinas de los símbolos astrales (figura 3). La figura apoya uno de sus pies sobre un globo terráqueo y otro sobre un espacio celeste donde se insinúa la formación de constelaciones astrológicas, mientras con una de sus manos sostiene un libro y con la otra señala una de las estrellas zodiacales, uniendo dos dimensiones naturales distintas, la terrenal y la espiritual. Debajo, en la misma página, un verso de Emilio Oribe recita:

¡Silencio! ¡Silencio!

Ahora, las estrellas, desde las doce casas del zodíaco se asoman a las puertas abiertas sobre el mar.

Junto a la imagen realizada para presentar la colección completa de las revistas, una viñeta del artista cordobés Francisco Vidal cerraba el índice (figura 4). La ilustración continuaba el estilo del trabajo de Warecki a través de la figura de una mujer con los ojos cerrados y sus brazos levantados en medio de un cielo con estrellas. Como podemos ver, los vínculos de Montes i Bradley con Córdoba no se circunscribían a su amistad con Juan Filloy. Una década

\footnotetext{
${ }^{5}$ Las figuras se encuentran en el Anexo 1, al final del artículo.

${ }^{6}$ Véanse los trabajos de Guillermo Fantoni compilados en un volumen de la revista Separata, que analizan distintos aspectos de la producción visual del artista: "Travesías del realismo mágico. Leónidas Gambartes entre la realidad y el ensueño" y "Culturas nativas, sensibilidad contemporánea: la obra tardía de Leónidas Gambartes", Separata, núm. 5 y 6, año III (octubre de 2003): 1-44.
} 
antes de lanzar el Boletín, el escritor dirigió Directrices. Revista Mensual de Cultura Artística y Literaria, junto con Julio Romero del Prado y Eduardo Gómez Ybáñez. Allí los artistas Francisco Vidal, Onofrio Palamara y Sorine colaboraron con la ornamentación general de la revista, mientras Nicolás Antonio de San Luis realizó la carátula con la silueta de un arquero resuelta en trazos geométricos.

A pesar de haber difundido únicamente dos números en 1929, la revista fue un testimonio de la vanguardia local no sólo por haber concentrado en sus páginas a un conjunto de importantes figuras vinculadas a las expresiones literarias más renovadoras de la época, sino también por la actitud disonante con la que Montes i Bradley se dirigía a los intelectuales que representaban a la izquierda más radicalizada, "aquellos que se dicen de vanguardia i son zurdos", a diferencia de quienes "están con nosotros en la verdadera posición estética de izquierda". 7

Esa diferenciación entre nosotros y ellos sería una de las tantas lógicas de confrontación que adquiriría la vanguardia para dividir el campo intelectual. Significativamente, a través de los mordaces artículos firmados en Boletín, una década más tarde el escritor utilizaría el mismo tono desafiante para desautorizar la labor de algunos protagonistas de la élite cultural e intelectual que ocupaban puestos dentro de la Dirección Municipal de Cultura, el Museo Municipal de Bellas Artes “Juan B. Castagnino” y la filial santafesina de la Sociedad Argentina de Escritores (SADE). En uno de esos textos transcribe las notificaciones de renuncia de varios escritores a la SADE de Santa Fe, incluida la suya, en la que critica la dualidad mostrada por el director de dicho organismo, en ese momento el xilógrafo y escritor Agustín Zapata Gollán, en relación a los acontecimientos que precedieron y sucedieron al golpe de junio de 1943, solicitándole su "impostergable e inmediata renuncia", así como de todos aquellos que se solidarizaron "con su pasividad condenable". ${ }^{8}$ En efecto, en varias oportunidades Montes i Bradley había manifestado su desaprobación con respecto a la acción militar: "degradante para quien alienta ideas pacifistas y cree todavía que sin clérigos i sin militares otra cosa sería la estirpe humana". 9

\footnotetext{
7 “nuestro número uno fué a la luz / nos elogiaron, estimularon i señalaron defectos, algunos, i nos combatieron inconsistentemente otros / aquéllos -no sabemos si los menos- están con nosotros en la verdadera posición estética de izquierda (...) / éstos -los otros- que se dicen vanguardia i son zurdos, conejos al decir de olivius, no nos podían considerar en otra forma”. Ricardo Ernesto Montes i Bradley, “...Señal que cabalgamos”, Directrices. Revista mensual de cultura artística y literaria, núm. 2, año I (septiembre de 1929): 38.

${ }^{8}$ Ricardo Ernesto Montes i Bradley, "La descomposición gremial de los escritores santafesinos", Boletín de Cultura Intelectual, núm. 24, año II (octubre de 1943): 133-136.

${ }^{9}$ Montes-Bradley (Ed.), El amigo de Filloy, 136.
} 
Esa actitud inconformista que parecía caracterizar su personalidad también se trasladaba a su forma de escribir, en apariencia anárquica, pero que en realidad continuaba la propuesta de la vanguardia ultraísta con el fin de distanciarse de las normas tradicionales de la gramática española y acercarse al lenguaje oral. En este sentido, el escritor sustituía la i griega por la i latina y utilizaba minúsculas después de un punto final. También modificó su propio apellido, generando en adelante algunas confusiones acerca de cómo era la forma correcta de escribirlo. Sin embargo, esta aparente simplificación, mantenida a lo largo de su trayecto literario, era contrarrestada con un vocabulario complejo desplegado a través de sus distintos artículos.

Algunas de esas peculiaridades que lo diferenciaban eran transferidas a sus publicaciones de circulación masiva donde podía experimentar propuestas estéticas y posiciones ideológicas. Por ejemplo, Boletín incluye su declaración editorial en un ejemplar de la segunda etapa que hacía un balance general y reproducía las tapas del resto de la colección. ${ }^{10}$ En dicha nota agradece a todos los artistas, periodistas, escritores, conferencistas y profesores que contribuyeron con el envío de textos o dibujos. Estas colaboraciones generaron un entramado que continuó desarrollándose a través de otros circuitos. Incluso distintas figuras del escenario cultural aparecieron en las fotografías de Boletín compartiendo reuniones o ideando nuevas propuestas editoriales, como puede verse, por ejemplo, en una de las instantáneas en donde Montes i Bradley, Fausto Hernández, Alfredo Laborde, Leónidas Gambartes y Ricardo Warecki preparan en la mesa de un café el volumen de los Cuadernos del Litoral dedicado a Pampa (1938), la primera parte de la trilogía poética de Fausto Hernández titulada In Mente (figura 5).

Montes i Bradley fue también quien se encargó de difundir en la revista Paraná siete poemas correspondientes al segundo tomo, que nunca llegó a ver la luz, acompañados por una pequeña viñeta de Alfredo Laborde con unos pájaros sobrevolando el paisaje fluvial. ${ }^{11}$ En la portada de Pampa realizada también por Laborde, un cielo nocturno se interrumpe por unas finas líneas trazadas a mano alzada que se extienden sobre el horizonte como el agua

\footnotetext{
${ }^{10}$ Ricardo Ernesto Montes i Bradley, “Algo en materia de cultura intelectual”, Boletín de Cultura Intelectual, núm. 25/33, año III (enero/septiembre de 1944): 15.

${ }^{11}$ Fausto Hernández, "De Ensueño”, Paraná, núm. 1 (invierno de 1941): 35-52. En el conflicto desplegado en torno a la SADE, Montes i Bradley vertió algunas palabras descalificadoras sobre Fausto Hernández lo que da indicios de que se pudo haber generado una enemistad entre ambos al menos desde 1943. Sobre este escritor se puede consultar: Érica Brasca, "La ciudad de Rosario en la obra poética de Fausto Hernández" (Rosario: 2018), disponible en: [http://www.celarg.org/trabajos/BRASCA-LA-CIUDAD-QUE-YO-INVENT--.pdf]
} 
del río, protagonista de su enigmática poesía. Al igual que Warecki y Vidal, Laborde dibuja unas estrellas luminosas que, además de las casas zodiacales, podrían evocar también los misterios del sueño, de la noche y de la creación indicando "un movimiento de formación del mundo o de sí mismo, un retorno a las fuentes acuáticas y luminosas, a los centros de energía terrenos y celestes"12 (figura 6). En varios dibujos realizados durante los años cuarenta para poemas y cuentos publicados en el diario La Capital, Warecki volvería a recurrir a la imagen de los cielos nocturnos y estrellados como una forma de aludir a la melancolía y el misterio. Algunos de esos textos fueron narrados por los mismos escritores que participaron en las revistas, periódicos o libros editados por Montes i Bradley como Carlos Carlino, Horacio Correas y Frida Schultz de Mantovani.

El artista, además, realizó pequeñas viñetas, ilustraciones de cuentos y publicidades que aparecieron fundamentalmente en la primera etapa del Boletín. Entre ese conjunto, las imágenes para textos de ficción literaria cumplían el rol de referencia visualizando escenas y personajes identificables dentro del relato, que podían comprenderse con una mirada rápida. En el cuento "El loco del callejón”, del escritor santafesino Luis María Albamonte, Warecki se detiene en las descripciones del suburbio imaginado por el autor, en las características del personaje y en una escena particular del texto, en la cual un loco roba a un bebé y se esconde en los callejones de un barrio marginal (figura 7).

La noche clava en la tierra sus tinieblas como pesadas banderas negras y los faroles de las esquinas son vacilantes audacias que agujerean sus sombras gigantes. Porque el suburbio tiene carne cansada y ojos malheridos, pronto el silencio es un ciego inmóvil que custodia las casuchas humildes. [...]

[El loco] Entra en un callejón que ensombrecen los muros de las casas elevadas y viejas. El moho que alimenta la humedad le da impresión de sótano y los murciélagos tejen en el espacio maloliente mallas invisibles. El loco y su carga parecen un jorobado tambaleante impulsado a una fuga imposible. ${ }^{13}$

El texto concluye cuando el supuesto delincuente simpatiza con el niño y se detiene a jugar con él hasta que llegan los familiares y vecinos con palos y puños amenazantes y, creyendo que iba

\footnotetext{
12 Jean Chevalier (Dir.), Diccionario de los símbolos (Barcelona: Herder, 1986), 489. Sobre estas temáticas: Jean Clair, Malinconia. Motivos saturninos en el arte de entreguerras (Madrid: Visor, 1999 [1996]); Raymond Klibansky, Erwin Panofsky, Fritz Saxl, Saturno y la melancolía: estudios de historia de la filosofía de la naturaleza, la religión y el arte (Madrid: Alianza, 2012 [1989]).

${ }^{13}$ Luis María Albamonte, "El loco del callejón”, Boletín de Cultura Intelectual, núm. 13, año II (noviembre de 1939): 9-10.
} 
a estrangularlo, "no pudieron dominar su indignación y lo lincharon...". La imagen despliega visualmente parte de la historia, pero también se relaciona con la temática de la marginalidad urbana que aparece de manera frecuente en la gráfica de Warecki. La noche constituye el momento preferido en estas representaciones a partir de ambientes que evocan los mundos inferiores y los bajos fondos en los bordes de la ciudad. Son por lo general escenarios habitados por vagabundos, delincuentes, borrachos y prostitutas que deambulan por las calles solitarias. Esa misma mirada de la urbe como espacio del pecado, la violencia y la desigualdad puede verse en la ilustración para el libro La ronda de los candiles, publicado por Félix Molina Téllez, en 1938. Allí una voluptuosa mujer desnuda se aferra a una cruz ortodoxa al resguardo de unos hombres que la acechan en medio de una noche de taberna en la fría Rusia (figura 8). Las botellas de vodka, las copas, la serpiente y las monedas hacen referencia al mundo de los prostíbulos donde los placeres carnales se aunaban con otros goces masculinos como el tabaco y el alcohol. En ocasiones esas composiciones de Warecki podían emparentarse con ciertas formas de la iconografía surrealista que mostraba los recodos de la metrópoli con sus objetos enigmáticos y terroríficos. André Bretón se refirió en distintas oportunidades a este redescubrimiento de los espacios urbanos ocultos del racionalismo arquitectónico: "La calle con sus inquietudes y miradas era mi verdadero, elemento: en ella como en ningún otro lugar yo tomaba el aire de lo eventual". ${ }^{14}$ Ricardo Warecki se acerca a aquella visión surrealista de la ciudad donde los seres marginales habitan rincones prohibidos que, a su vez, son los mismos escenarios imaginados por los autores en los cuentos y poemas publicados.

En la producción gráfica del pintor, las figuras femeninas delicadas de algunos de sus trabajos contrastan con otras más carnales; los paisajes naturales envueltos en una atmósfera limpia y misteriosa conviven con escenarios caóticos caracterizados por la extrañeza, mientras que los cuerpos abatidos por la melancolía coexisten con seres malignos. Al igual que otros artistas interesados en las corrientes estéticas de entreguerras, la representación de figuras melancólicas aparece con distintas variaciones en su obra. En el dibujo para el cuento “El príncipe Enrique”, de Agustín Zapata Gollán, publicado en mayo de 1940, un joven fastidiado observa el mar tormentoso que lo envuelve. ${ }^{15}$ La narración aludía a la vida del

\footnotetext{
${ }^{14}$ Victoria Combalía Dexeus, "Volviendo al surrealismo", París y los surrealistas, cat. exp (Bilbao: Museo de Bellas Artes de Bilbao, junio-septiembre de 2005), 15. En el marco local estos temas fueron trabajados en Guillermo Fantoni, Berni entre el surrealismo y Siqueiros. Figuras, itinerarios y experiencias de un artista entre dos décadas (Rosario: Beatriz Viterbo, 2014).

15 Agustín Zapata Gollán, "El príncipe Enrique”, Boletín de Cultura Intelectual, núm. 19, año II (mayo de 1940): 75.
} 
heredero de la monarquía portuguesa antes de la expedición de América, un personaje solitario "ensimismado en sus estudios y fantasías" que podía pasar horas admirando la inmensidad del océano. La imagen (figura 9) muestra una afinidad con sus ilustraciones de cuentos infantiles difundidas en "La página para los niños", del diario La Capital, en donde utiliza motivos afines a la cultura y las tradiciones artísticas occidentales junto a recursos visuales provenientes de las revistas infantiles y la historieta. ${ }^{16}$

Paralelamente, Warecki trabajó desde los años treinta realizando publicidades gráficas para distintas empresas de la ciudad. Algunas de las imágenes elaboradas para la Sociedad de Electricidad de Rosario y La Comercial de Rosario fueron publicadas en el Boletín (figura 10). Como señalamos en otro texto, la representación de la ciudad industrial, el desarrollo de habilidades técnicas y la fantasía de la electrificación fueron algunos de los motivos desplegados en las publicidades para la compañía eléctrica, ${ }^{17}$ mientras que para las empresas albergadas en La Comercial se destacaron las vistas del moderno edificio o las imágenes referidas a las posibilidades que podía generar la obtención de un crédito. Si bien las vistas arquitectónicas para La Comercial no están firmadas por Warecki, el artista realizó otros anuncios para las sociedades mercantiles desarrolladas en ese espacio, que había albergado una compañía de seguros, una empresa financiera y departamentos de renta, siguiendo la estética racionalista moderna. Junto a esos avisos propagandísticos dispersos en distintos diarios de la época, también dibujó fachadas de edificios para revistas, lo que nos permite pensar que estas imágenes podrían ser de su autoría. Los últimos números del Boletín incorporaron, asimismo, algunos trabajos para la Sociedad de Electricidad de Rosario que parecieran ser del artista, aunque tampoco poseen una firma visible.

De todos modos, la cantidad de entregas del Boletín fue menguando a tal punto que los últimos ejemplares reunían cinco números juntos. En su corpus epistolar, Montes i Bradley mencionó en varios momentos haber tenido inconvenientes con el gremio de los trabajadores gráficos, episodios que se agravaron luego de las medidas laborales implementadas por el peronismo, que incluían un sistema de salarios mínimos, descanso

\footnotetext{
${ }^{16}$ Elisabet Veliscek, "Los cuentos imaginados por Ricardo Warecki. Figuras infantiles y espacios soñados", Eadem Utraque Europa. Revista Semestral de Historia Cultural e Intelectual, núm. 20, año XV (agosto de 2019): 285-314.

${ }^{17}$ Elisabet Veliscek, "Contra la guerra y el peronismo. Las imágenes de Ricardo Warecki en el diario Crónica de Rosario", Rosario (documento de trabajo), 2020.
} 
dominical, vacaciones pagas y la extensión de la jubilación de tal manera que abarcara a los empleados de comercio y trabajadores industriales. Debido a esto, en julio de 1946, el escritor se refería con incertidumbre al destino de la publicación en un mensaje a su compañero Juan Filloy:

Me alegra que le guste el boletín, que ya sabe usted con cuanto cariño elaboro, i desearía sostener, aunque...a decirle verdad, no sé por cuantos números más podrá continuar apareciendo. Si hai que pagar jubilación a los gráficos — como se anuncia-, la nueva suba en su costo dará al traste con mis afanes, posiblemente. ${ }^{18}$

Si bien los sindicatos gráficos tuvieron en general desde finales del siglo XIX una orientación anarquista o socialista, como un modo de enfrentar al poder y diferenciarse del oficialismo, desde las elecciones de 1946 el gremio se fue desarticulando hasta pasar a ser conducido enteramente por obreros peronistas. Mientras tanto, desde Rosario se organizaba una política de oposición muy fuerte al gobierno a través de la Federación Gráfica Rosarina, la cual empezó a tener un rol fundamental luego del repliegue de la asociación bonaerense, aunque fue imposible contener la adhesión y multiplicación en el seno del gremio de los entusiastas seguidores del nuevo partido. ${ }^{19}$

En relación a este conflicto, en junio de 1948, Montes i Bradley protestaba sobre la manera en que los obreros de la imprenta podían retardar o directamente paralizar una publicación si él mismo no se encargaba de supervisarla: "si uno no está presente, los gráficos que son peronistas, lo tiran a matar". Y aunque la última entrega de Boletín lleva fecha de 1947, en realidad el escritor explica que en ese momento estaba todavía en proceso de edición, pero que "por razones de colección”, iba a llevar fecha pretérita. ${ }^{20}$ Es posible suponer, entonces, que la desaparición del periódico haya estado íntimamente relacionada con las disputas generadas al interior del gremio de trabajadores gráficos y la consiguiente organización de un núcleo de obreros ligados al peronismo, entusiasmados por los aires de transformación que implicaban la conquista de derechos laborales y beneficios sociales, como producto de un largo proceso de lucha y reivindicación gremial. Probablemente el escritor no estaba en condiciones de afrontar los nuevos costos que demandaba la regulación

\footnotetext{
${ }^{18}$ Montes-Bradley (Ed.), El amigo de Filloy, 124-125.

${ }^{19}$ Nelson Ferrer, "Los gráficos en la era peronista", Historia de los gráficos argentinos. Sus luchas, sus instituciones 1857-1957 (Buenos Aires: Dos Orillas, 2008), 325-354. También Rosario fue la sede del Segundo Congreso Ordinario de la Federación Argentina de Trabajadores de Imprenta (FATI), llevado a cabo en noviembre de 1948.

${ }^{20}$ Montes-Bradley (Ed.), El amigo de Filloy, 146.
} 
de la labor de trabajadores de las imprentas, a la que se sumaba la de los periodistas, lo que significó el abandono de sus emprendimientos editoriales para finalmente terminar radicándose en México hacia principios de los años cincuenta.

\section{Río que une y no divide}

En paralelo a la labor desplegada en Boletín, entre 1941 y 1943 Montes i Bradley dirigió la revista Paraná que se desarrolló en cuatro gruesos volúmenes impresos en papel obra y tapas de cartulina, con una tirada que rondaba entre 1500 y 1600 ejemplares y una distribución iniciada de manera trimestral en el invierno de 1941, aunque interrumpida al año siguiente hasta el otoño de 1943, cuando salió el último tomo con cuatro números juntos. La revista se imprimó en los Talleres Gráficos de Emilio Fenner, el cual tuvo a su cargo otras publicaciones del escritor. ${ }^{21}$ El lema consignado en la solapa interior de la revista: "Paraná, columna vertebral del litoral. Rica vena, tenso nervio, clara voz de Argentina intelectual. Corrientes, Chaco, Entre Ríos, Formosa, Misiones, Santa Fe, diciendo sus inquietudes”, daba cuenta de un vasto territorio geográfico vinculado a la obra de autores provenientes de la amplia zona del litoral argentino.

En la nota editorial, firmada por Montes i Bradley con el seudónimo "El almadiero", hacía referencia a un ámbito geográfico delimitado naturalmente por las barrancas y declives del río Paraná, como si esta sintaxis espacial determinara un lazo espiritual que uniera diferentes regiones y poblaciones, expresiones literarias y artísticas, borrando las fronteras políticas. También, el emblema del sumario realizado por Warecki aludía a la fecundidad del río a partir de la figura de una mujer desnuda vertiendo agua de una vasija (figura 11).

\footnotetext{
${ }^{21}$ Junto con la casa impresora de Vicente Pomponio, la de Fenner era una de las más importantes de Rosario y ambas habían tenido una vasta experiencia en la edición de revistas culturales, periódicos y libros. La empresa llegó de Europa y se instaló en la ciudad hacia 1900, como producto de la expansión de las industrias gráficas en la Argentina. Desde una perspectiva cultural, las relaciones entre el arte y la industria contribuyeron a una profesionalización de la producción gráfica, a la aparición de numerosos gremios creados por los intensos reclamos sociales y al nacimiento de la Sociedad Industrial Gráfica de Rosario, que desde 1927 comenzó a editar una revista. A mediados de la década de 1930 se habían creado en Rosario más de cincuenta talleres gráficos, entre ellos, Borsellino Impresos, Peuser S.A, Talleres Gráficos Valdez, Talleres Gráficos Virgolini Martínez — donde se imprimió la mayor cantidad de afiches de la época-, Establecimiento Gráfico de Oscar Sudylosky, la imprenta Romiti, y muchas otras. Cfr. Luis F. San Miguel, "Historia de las imprentas en Rosario", Revista de Historia de Rosario, XXXVII, núm. 45 (2005): 63-69.
} 
PARANA pretende ser eso i solo eso: PARANA. Río que une i no divide, ata i no separa; río que está en la toponimia nacional más que como una referencia mera; como algo más que un paisaje estirado por miles de kilómetros al oro de un sol magnífico, en el azul diáfano de un ámbito grandioso i junto al verde de una vegetación luminosa poblada desde el hombre abajo, de seres de línea opuesta i ágil; como mucho más que un propicio escenario histórico [...]. Pueblo que le cruza i le navega aguas arriba i abajo, señor de un mundo que cierran sus flores i sus pájaros, sus mitos y sus leyendas, sus creencias i sus lenguas, sus artes i sus ciencias. Pueblo que es uno en la profundidad i el arraigo de sus esencias telúricas. Pueblo que i aun el aluvión cambia en su etiología por más que gringa se vuelva su pampa en el espejismo civilizante. ${ }^{22}$

Inscriptos, por lo general, en las corrientes literarias realistas y regionalistas de los años treinta y cuarenta, los escritores que a menudo colaboraron en las publicaciones de Montes i Bradley pusieron en juego una problemática intelectual relacionada con el concepto de "región” o de "zona". ${ }^{23}$ A grandes rasgos, la idea del regionalismo literario era una noción emparentada con las valoraciones costumbristas y pintoresquistas de un ámbito geográfico en particular, en este caso, el litoral argentino y su mundo de referencias, que se ha entendido como retrógrado frente a las innovaciones de la literatura moderna o vanguardista de los grandes centros urbanos. Si bien distintas figuras de la alta literatura se interesaron por la descripción de las características estéticas y geográficas de determinados espacios, nunca se ha insinuado que estos autores estuvieran amenazados por la seducción del paisaje provinciano o del color local. Entonces, cuando se hablaba de literatura regionalista en los años cuarenta a menudo se hacía de una forma despectiva para referirse a los escritores del interior que producían textos imbuidos en una estética "telúrica" y "retardataria" para un mercado provincial. ${ }^{24}$

A pesar de que esta concepción era bien conocida en la época, Montes i Bradley lejos de querer apartarse de una narrativa centrada en un territorio definido- acentuó esa perspectiva espacial para identificar el arte y la literatura de la zona con una pertenencia

\footnotetext{
${ }^{22}$ El almadiero, "Desde la almadía”, Paraná, núm. 1 (invierno de 1941): 7.

${ }^{23}$ En particular nos centramos en dos trabajos que problematizaron dicha concepción analizando casos de escritores argentinos que le dieron una vuelta innovadora a la idea del regionalismo. Véase Sergio Delgado, "Realismo y región. Narrativas de Juan Carlos Dávalos, Justo P. Sáenz, Amaro Villanueva y Mateo Booz", en María Teresa Gramuglio (Dir.), Historia crítica de la literatura argentina, vol. 6 (Buenos Aires: Emecé, 2002), 345-366, y Enrique Foffani y Adriana Mancini, "Más allá del regionalismo: la transformación del paisaje”, en Elsa Drucaroff (Dir.), Historia crítica de la literatura argentina, vol. 11 (Buenos Aires: Emecé, 2000), 261-291.

${ }^{24}$ Eduardo D'Anna señala: 'Los regionalistas fueron todos tratados como literatos de segunda clase. Por ello es frecuente comprobar que en Buenos Aires se editaban 'antologías regionales', o que los libros de los regionalistas eran agrupados en colecciones 'de las provincias', pero nunca revistaban en un plano de igualdad con los escritores centrales”. Eduardo D’Anna, La literatura de Santa Fe. Un análisis crítico (Santa Fe: Espacio Santafesino Ediciones, 2018), 101.
} 
geográfica y cultural en torno al ámbito del Litoral. La revista Paraná construyó en gran parte una argumentación sostenida en ese relato, no carente de transgresiones innovadoras en los textos de algunos escritores como Fausto Hernández o Mateo Booz, por dar algunos ejemplos, aunque también puede encontrarse ese lugar compartido en los cuentos y poemas divulgados en Boletín.

El paisaje litoraleño generó una construcción identitaria en donde se diluyeron las fronteras para abarcar una zona amplia en la que podían confluir desde la selva chaqueña y las islas del río Paraná hasta la pampa gringa o la fauna correntina. Sin embargo, frente a una narrativa que apostaba a la semejanza natural, a la descripción realista del entorno y en ocasiones a la visión metafórica, las imágenes transformaron los sentidos de los textos apostando por la ensoñación surrealista o a la incoherencia aparente. El regionalismo de algunos de estos cuentos y textos breves es reconfigurado a partir de las ilustraciones que aluden a marginalidad urbana de los suburbios, a ciertos escenarios urbanos y naturales pesadillescos, a experiencias ligadas al mundo de lo imposible o a universos interiores infundidos en la melancolía saturnina. Algunas de las viñetas y dibujos de Leónidas Gambartes, Amadeo López Armesto, Pedro Hermenegildo Gianzone, Alfredo Laborde y Ricardo Warecki realizadas para el Boletín y la revista Paraná, confluyeron de esta forma, desplegando una serie de motivos asociados al poder de la fantasía.

Una de las principales características de los emprendimientos de Montes i Bradley era el intercambio entre literatura y artes plásticas. Ese interés por las artes visuales quedaba plasmado en la impresión de linóleos originales, en la numerosa cantidad de ilustraciones y en las reproducciones en color de obras artísticas cuyas láminas eran pegadas en el borde superior de gruesas cartulinas de tonos neutros, enmarcadas con una línea en color oro, plata o alguna tonalidad afín. A diferencia de los dibujos que acompañaban los poemas y relatos literarios, esas imágenes estaban separadas del texto y difundían obras de artistas rosarinos y santafesinos respondiendo a una nueva estrategia cultural que privilegiaba la colección de grabados y piezas gráficas, así como de fotografías y láminas a color, producto de una tendencia general que parecía tener "una función incluso más importante en los países latinoamericanos que en las metrópolis", donde no era posible contar con instituciones estables ni colecciones públicas de dimensiones similares. ${ }^{25}$

\footnotetext{
${ }^{25}$ Paulette Silva Beauregard, "Un lugar para exhibir, clasificar y coleccionar: la revista ilustrada como una galería del progreso", en Beatriz González Stephan y Jens Andermann (Eds.), Galerías del progreso. Museos, exposiciones y cultura visual en América Latina (Rosario: Beatriz Viterbo, 2006), 373-406.
} 
En relación con esas reproducciones, el resto de las imágenes cumplía una función ilustrativa extendiendo el sentido de los textos, añadiendo nuevas significaciones derivadas del universo imaginario del artista o presentando a los escritores y su obra a través de pequeñas caricaturas. Algunas de las viñetas apelaban a los recursos y motivos provenientes de la gráfica expresionista y surrealista exhibiendo atmósferas oníricas, ojos mutilados y cuerpos amorfos mediante el uso de líneas distorsionadas y formas exageradas, que funcionaban como un contrapunto de las narraciones basadas, por lo general, en la descripción de paisajes, ambientes, tipos y costumbres del Litoral. Sin distanciarse completamente de este mundo referencial, otro tipo de textos incursionaban en el misterio, recreando las posibilidades narrativas que ofrecía la vivencia interior de los personajes o el gusto por la aventura, la fantasía y el horror. En diálogo con este tipo de relatos Warecki volvió a ilustrar un cuento de Luis María Albamonte para el volumen de 1943 mediante un grabado en linóleo. En la imagen para "La terrible mentira de Sámbur" (Figura 12), los trazos gruesos y sueltos, las formas angulosas y los surcos de la superficie recuerdan a las xilografías de algunos expresionistas alemanes como Ernst Ludwig Kirchner y Karl Schmidt-Rottluff. El grabado fue impreso sobre una lámina de un verde profundo, prolongando la imagen de una naturaleza que se transforma en un paisaje terrorífico con troncos astillados y árboles antropomorfos, en donde lo humano se entrecruza con lo vegetal. Esa dimensión imaginaria sintoniza con las temáticas desarrolladas en algunas piezas de la gráfica expresionista que se inspiraron en los relatos de terror de la infancia en los dibujos infantiles de los cuentos populares y en los íconos primitivos rusos. ${ }^{26}$

Uno de los rasgos que diferencia esta ilustración de otras imágenes del artista más apegadas a la historia central del cuento es la atención sobre determinados fragmentos del relato para potenciar el efecto de misterio. La estampa no pareciera representar una escena importante sino más bien detenerse en ciertos momentos de la narración: "se le pegaba en las manos la humedad sombría del bosque"; "nada podía explicar claramente su terror. Pero una sombra, él lo sabía, traía el motivo de su miedo"; “y echó a correr. Corría en el sentido contrario al que llevaba Yensi. Iba hacia el pueblo [...]. Sus gritos eran la desesperación fabulosa de todo lo que temblaba bajo la noche a un paso de la locura de una tormenta". ${ }^{27}$

\footnotetext{
${ }^{26}$ Figura Starr (Ed.), German Expressionism: The graphic impulse, cat. exp (New York: The Museum of Modern Art, 2011).

${ }^{27}$ Luis María Albamonte, "La terrible mentira de Sámbur”, Paraná, núm. 4-7 (1943): 9-22.
} 
El turbador relato de Albamonte se producía en un mundo de ensueño que sugería la fuerza alucinatoria y la subjetividad de la percepción humana a partir de la introducción de formas provenientes de la literatura fantástica, aunque sin olvidar el enclave regional.

Por otra parte, la mirada fragmentaria volvía a aparecer en la ilustración para el relato "I ahora, Pedro", de Montes i Bradley, publicado en el primer tomo de la revista (figura 13). ${ }^{28}$ Entre las bocanadas de humo de las torres fabriles se multiplican partes de edificios y calles empedradas cubiertas de sangre, así como objetos y figuras yuxtapuestas ligadas al ambiente nocturno propio de las orillas, en el que aparecen animales, hombres borrachos y seres soñando sobre los desechos de la ciudad y el crimen. También en este caso Warecki recurre a distintos episodios del cuento que aparecen todos mezclados siguiendo el estilo de las composiciones fragmentadas de los fotomontajes de entreguerras, que daban una nueva relevancia a la práctica de la fotografía y el recorte de imágenes en el contexto del cine, las revistas ilustradas y la reproducción masiva de imágenes.

En ese mismo número de la revista Warecki realizó dos ilustraciones a tinta para el texto "Momentos de la muerte transparente" de Félix Molina Téllez (figuras 14 y 15), una de ellas luego reimpresa en el libro con el mismo título que el autor publicó en 1949 con láminas de Pelissier. ${ }^{29}$ En la imagen principal aparecen seres cadavéricos e informes suspendidos en un paisaje de troncos y ramajes secos junto a un campanario y una mujer desnuda con su cuerpo torsionado y los cabellos al viento.

La figura femenina sostiene una estrella luminosa que parece estar a punto de escapársele de entre los dedos por la velocidad con la que avanza sobre un caballo, animal vinculado al planeta Marte, cuya visión se considera presagio de guerra. ${ }^{30}$ También aquí el artista recurre aimágenes fragmentarias para ilustrar distintas partes del texto en donde los límites de la pampa configuran el escenario de una tragedia. Unos años antes el artista había representado a una mujer sobre un caballo para la tapa del libro Horas del alma, de Aristide F. J. Maañón, pero en ese caso el enorme reloj del fondo relacionaba la escena con el paso del tiempo.

La filiación del artista al universo onírico no se circunscribió a su intervención en la revista Paraná, pues realizó numerosas imágenes de este estilo para ilustrar cuentos de

\footnotetext{
${ }^{28}$ Ricardo Ernesto Montes i Bradley, “¿I ahora, Pedro?”, Paraná, núm. 1 (invierno de 1941), pp. 111-116.

${ }^{29}$ Félix Molina Téllez, "Momentos de la muerte transparente”, Paraná, núm. 4-7 (1943): 105-114.

${ }^{30}$ Juan Eduardo Cirlot, Diccionario de símbolos (Barcelona: Labor, 1995), 110.
} 
escritores locales publicados en diarios, revistas y libros. Incluso en momentos más tardíos de su itinerario la imaginación surrealista siguió acompañando algunos de sus dibujos. Un ejemplo es la ilustración a tinta que realizó para un texto de Luján Carranza en el ejemplar de 1963 de la revista de artes y letras Cauce, en donde incorpora ojos amputados, enigmáticas sombras proyectadas y cuerpos retorcidos.

Esas imágenes de Warecki contrastaban con las acuarelas, témperas aguadas y pequeñas viñetas inspiradas en los realismos de entreguerras que confeccionó para otros cuentos de la revista Paraná, en donde asoman espacios cotidianos y personajes populares más ligados al mundo de los magazines y dibujos animados (figura 16). También la revista sirvió como un campo de experimentación en donde incorporó un gran retrato del poeta Olegario Andrade realizado sobre una placa de yeso raspado a la manera de un grabado en hueco (figura 17).

Siguiendo el perfil de su fotografía más conocida, el artista reprodujo además su imagen en un grafito para una entrega del Boletín que continuaba el estilo del grabado. Esas experiencias gráficas fueron posibles en el marco de dos publicaciones que permitieron el desarrollo de redes intelectuales e intercambios artísticos en la ciudad de Rosario. Es indudable que la ampliación del mercado lector hacia los años treinta y cuarenta supuso la formación de públicos y circuitos de divulgación más extensos que tuvieron una correlación en la amplificación de medios laborales donde se desempeñaron periodistas, escritores e ilustradores vinculados a las tendencias estéticas modernas. Por su amplia experiencia en la industria editorial y periodística, Ricardo Warecki fue uno de los artistas elegidos con mayor frecuencia para formar parte de esos proyectos. 


\section{Bibliografía}

Albamonte, Luis María. "El loco del callejón”. Boletín de Cultura Intelectual, año II, núm. 13 (noviembre, 1939): 9-10.

Albamonte, Luis María. “La terrible mentira de Sámbur”. Paraná, núm. 5-7 (1943): 9-22.

Brasca, Érica. “La ciudad de Rosario en la obra poética de Fausto Hernández”. Rosario, 2018. http://www.celarg.org/trabajos/BRASCA-LA-CIUDAD-QUE-YO-INVENT--.pdf.

Chevalier Jean (Dir.). Diccionario de los símbolos. Barcelona: Herder, 1986.

Cirlot, Juan Eduardo. Diccionario de símbolos. Barcelona: Labor, 1995.

Clair, Jean. Malinconia. Motivos saturninos en el arte de entreguerras. Madrid: Visor, 1999.

Combalía Dexeus, Victoria. "Volviendo al surrealismo". París y los surrealistas, cat. exp., Bilbao: Museo de Bellas Artes de Bilbao, junio-septiembre, 2005.

D’Anna, Eduardo. La literatura de Santa Fe. Un análisis crítico. Santa Fe: Espacio Santafesino Ediciones, 2018.

Delgado, Sergio. “Realismo y región. Narrativas de Juan Carlos Dávalos, Justo P. Sáenz, Amaro Villanueva y Mateo Booz". En María Teresa Gramuglio (Dir.), Historia crítica de la literatura argentina, vol. 6. Buenos Aires: Emecé, 2002.

Dosse, François. El arte de la biografía: entre historia y ficción. México: Universidad Iberoamericana, 2007.

El almadiero, “Desde la almadía". Paraná, núm. 1 (invierno, 1941): 7.

Fantoni, Guillermo. “Travesías del realismo mágico. Leónidas Gambartes entre la realidad y el ensueño" y "Culturas nativas, sensibilidad contemporánea: la obra tardía de Leónidas Gambartes”. Separata, año III, núms. 5 y 6 (octubre de 2003): 1-44.

Fantoni, Guillermo. Berni entre el surrealismo y Siqueiros. Figuras, itinerarios y experiencias de un artista entre dos décadas. Rosario: Beatriz Viterbo, 2014.

Ferrer, Nelson. "Los gráficos en la era peronista". En Historia de los gráficos argentinos. Sus luchas, sus instituciones 1857-1957. Buenos Aires: Dos Orillas, 2008.

Foffani Enrique, y Adriana Mancini. "Más allá del regionalismo: la transformación del paisaje”. En Elsa Drucaroff (Dir.), Historia crítica de la literatura argentina, vol. 11. Buenos Aires: Emecé, 2000. 
Guevara, Martina. "La construcción de un centro cultural desde la periferia: Juan Filloy y el Museo de Bellas Artes de Río Cuarto". Corpus. Archivos Virtuales de la Alteridad Americana, $8, \quad$ núm. 1 (enero-junio, 2018): 1-22. https://doi.org/10.4000/corpusarchivos.2107.

Hernández, Fausto. “De Ensueño”. Paraná, núm. 1 (invierno, 1941): 35-52.

Klibansky, Raymond, Erwin Panofsky y Fritz Saxl. Saturno y la melancolía: estudios de historia de la filosofía de la naturaleza, la religión y el arte. Madrid: Alianza, 2012.

Molina Téllez, Félix. "Momentos de la muerte transparente”. Paraná, núm. 4-7 (1943): 105114.

Montes i Bradley, Ricardo Ernesto. “¿I ahora, Pedro?”. Paraná, núm. 1 (invierno, 1941), pp. 111-116.

Montes i Bradley, Ricardo Ernesto. “...Señal que cabalgamos”. Directrices. Revista Mensual de Cultura Artística y Literaria, I, núm. 2 (septiembre, 1929): 38.

Montes i Bradley, Ricardo Ernesto. "Algo en materia de cultura intelectual”. Boletín de Cultura Intelectual, III, núms. 25/33 (enero/septiembre, 1944): 15.

Montes i Bradley, Ricardo Ernesto. "La descomposición gremial de los escritores santafesinos”. Boletín de Cultura Intelectual, II, núm. 24 (octubre, 1943): 133-136.

Montes-Bradley Eduardo (Ed.). El amigo de Filloy. Cartas de R-E Montes i Bradley a Juan Filloy (1935-1976). Charlottesville: HTP Press, 2016.

San Miguel, Luis F. "Historia de las imprentas en Rosario". Revista de Historia de Rosario, XXXVII, núm. 45 (2005): 63-69.

Silva Beauregard, Paulette. "Un lugar para exhibir, clasificar y coleccionar: la revista ilustrada como una galería del progreso". Beatriz González Stephan y Jens Andermann (Eds.), Galerías del progreso. Museos, exposiciones y cultura visual en América Latina. Rosario: Beatriz Viterbo, 2006.

Starr Figura (Ed.). German Expressionism: The Graphic Impulse, cat. exp. New York: The Museum of Modern Art, 2011.

Veliscek, Elisabet. "Contra la guerra y el peronismo. Las imágenes de Ricardo Warecki en el diario Crónica de Rosario". Rosario (documento de trabajo), 2020. 
Veliscek, Elisabet. "Los cuentos imaginados por Ricardo Warecki. Figuras infantiles y espacios soñados". Eadem Utraque Europa. Revista Semestral de Historia Cultural e Intelectual, XV, núm. 20 (agosto, 2019): 285-314.

Zapata, Gollán. Agustín. “El príncipe Enrique”. Boletín de Cultura Intelectual, II, núm. 19 (mayo de 1940): 75. 


\section{Anexo 1: Figuras}

Figura 1. Exlibris de Ricardo Warecki para el libro de Ricardo Ernesto Montes i Bradley, Alabado sea tu nombre (Rosario, Carpetas del Grillo: 1944).

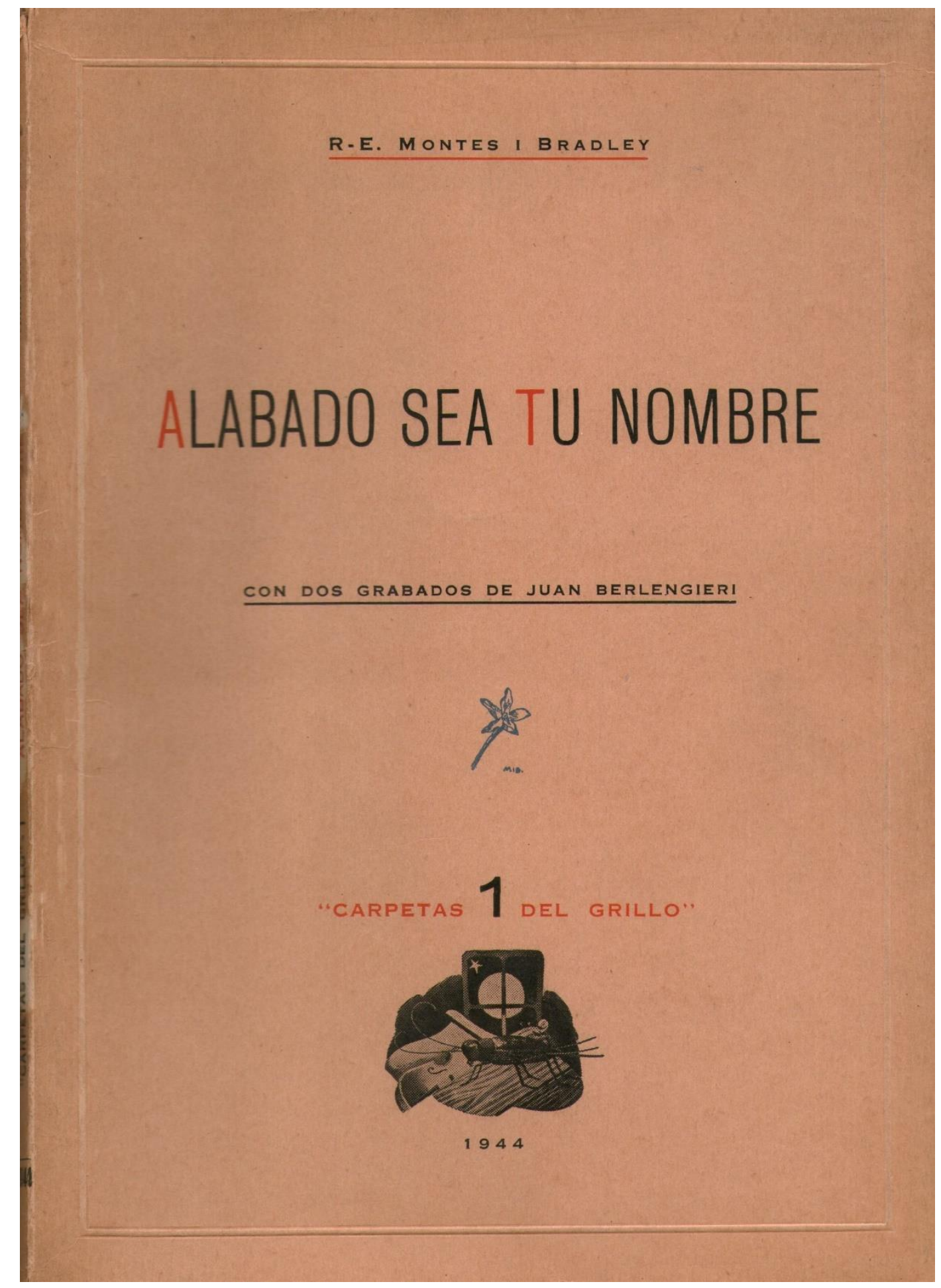


Figura 2. Ilustración de Ricardo Warecki para el libro de Ricardo Ernesto Montes i Bradley, Resurrección de Lenzoni (Rosario, Ed. Palace: 1945).

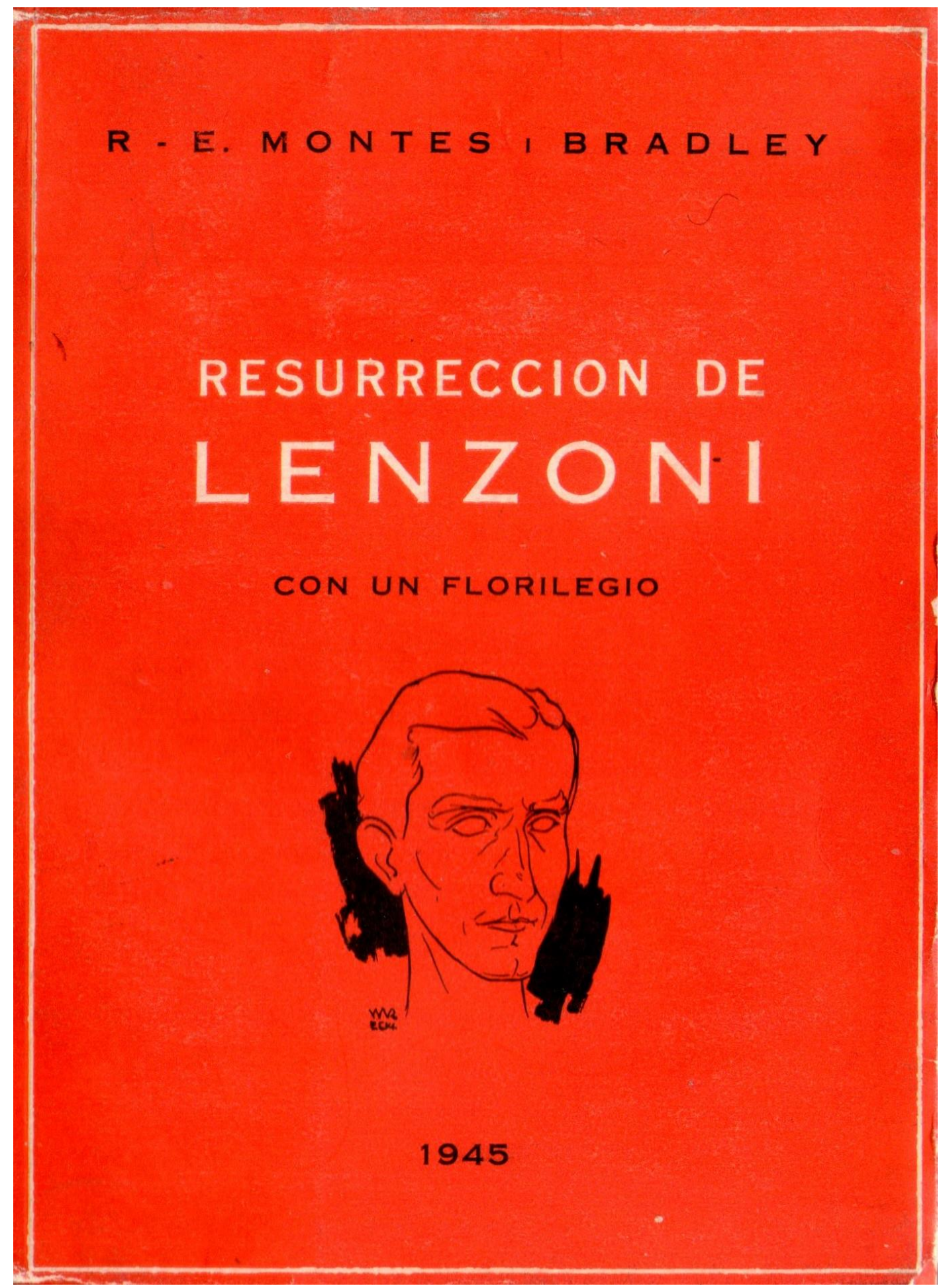


Figura 3. Ilustración de Ricardo Warecki para la tapa de la colección completa del Boletín de Cultura Intelectual (Rosario, 1938-1947).

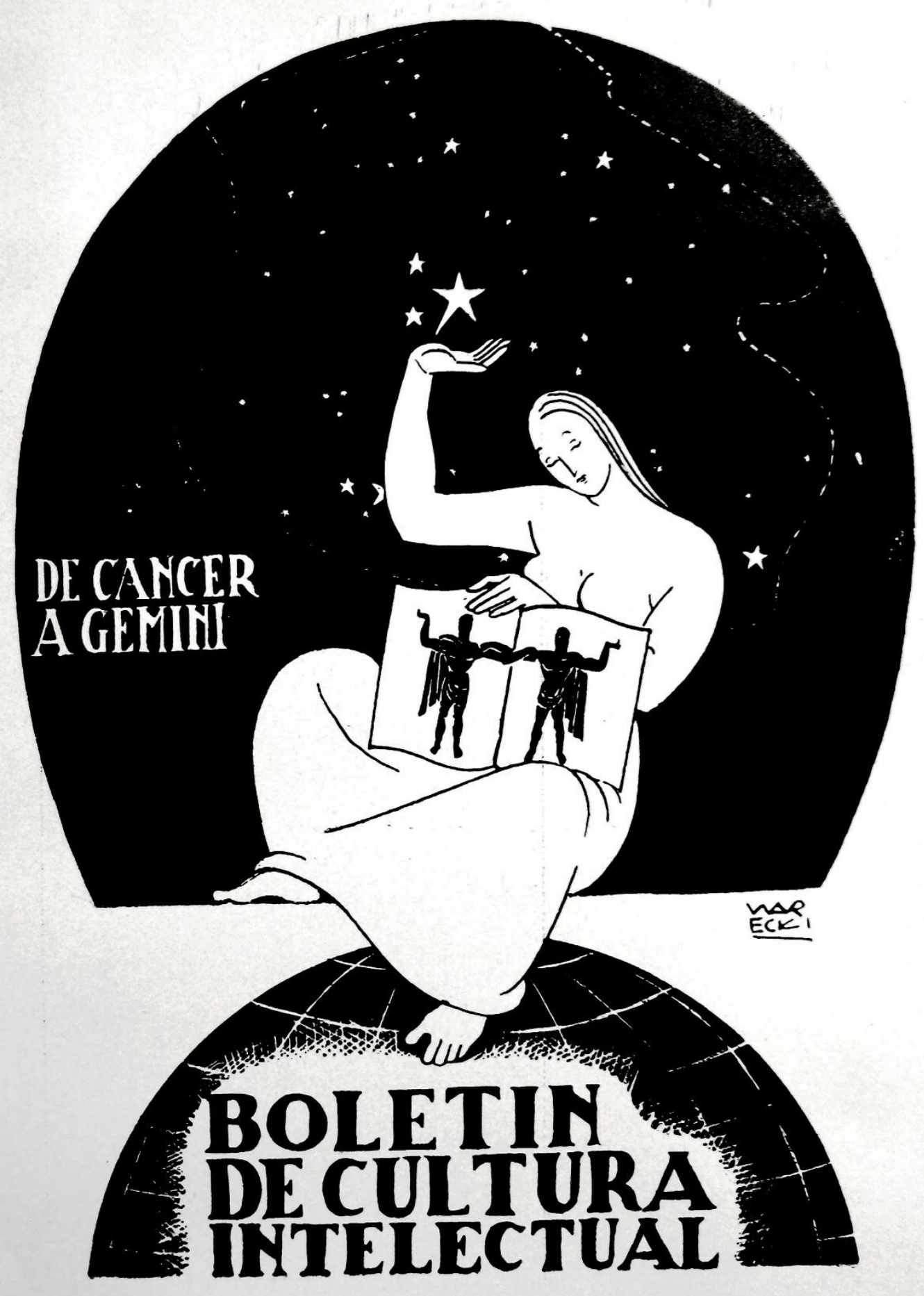


Figura 4. Ilustración de Francisco Vidal para el índice de la colección completa del Boletín de Cultura Intelectual (Rosario, 1938-1947).

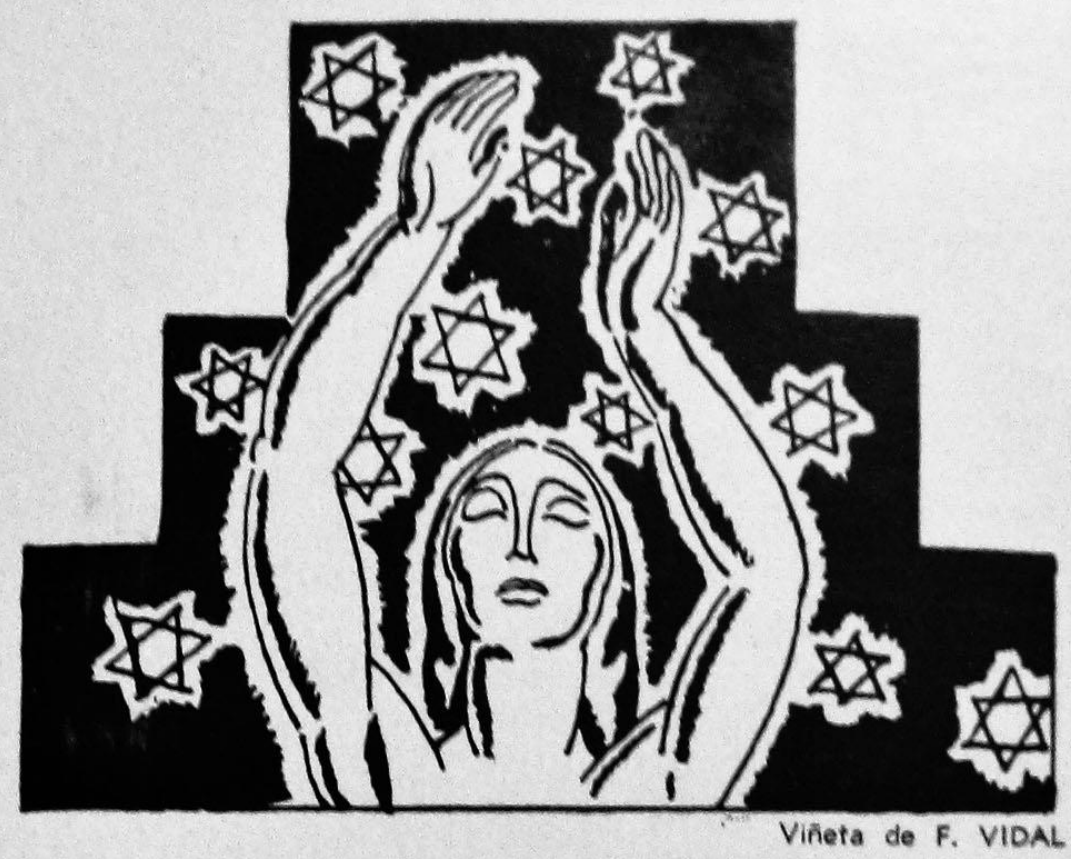

I N D I C E 
Figura 5. Fotografía ubicada en el Boletín de Cultura Intelectual, I, núm. 10 (marzo de 1939), p. 80. De izquierda a derecha: Leónidas Gambartes, Ricardo Warecki, Ricardo E. Montes i Bradley, Alfredo Laborde, Fausto Hernández.

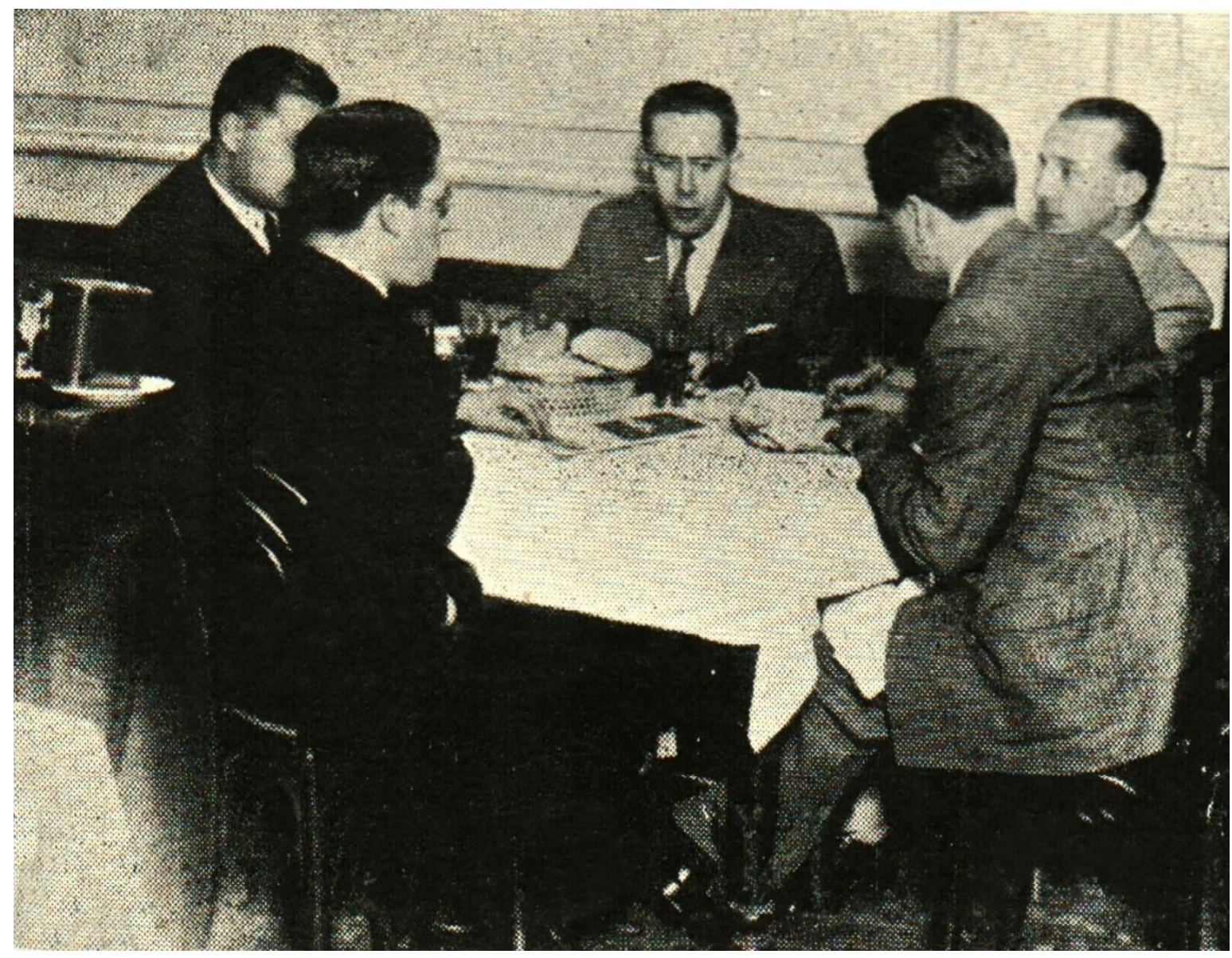


Figura 6. Cubierta de Alfredo Laborde para el libro de Fausto Hernández, In mente I: Pampa (Rosario, Cuadernos del Litoral: 1938).

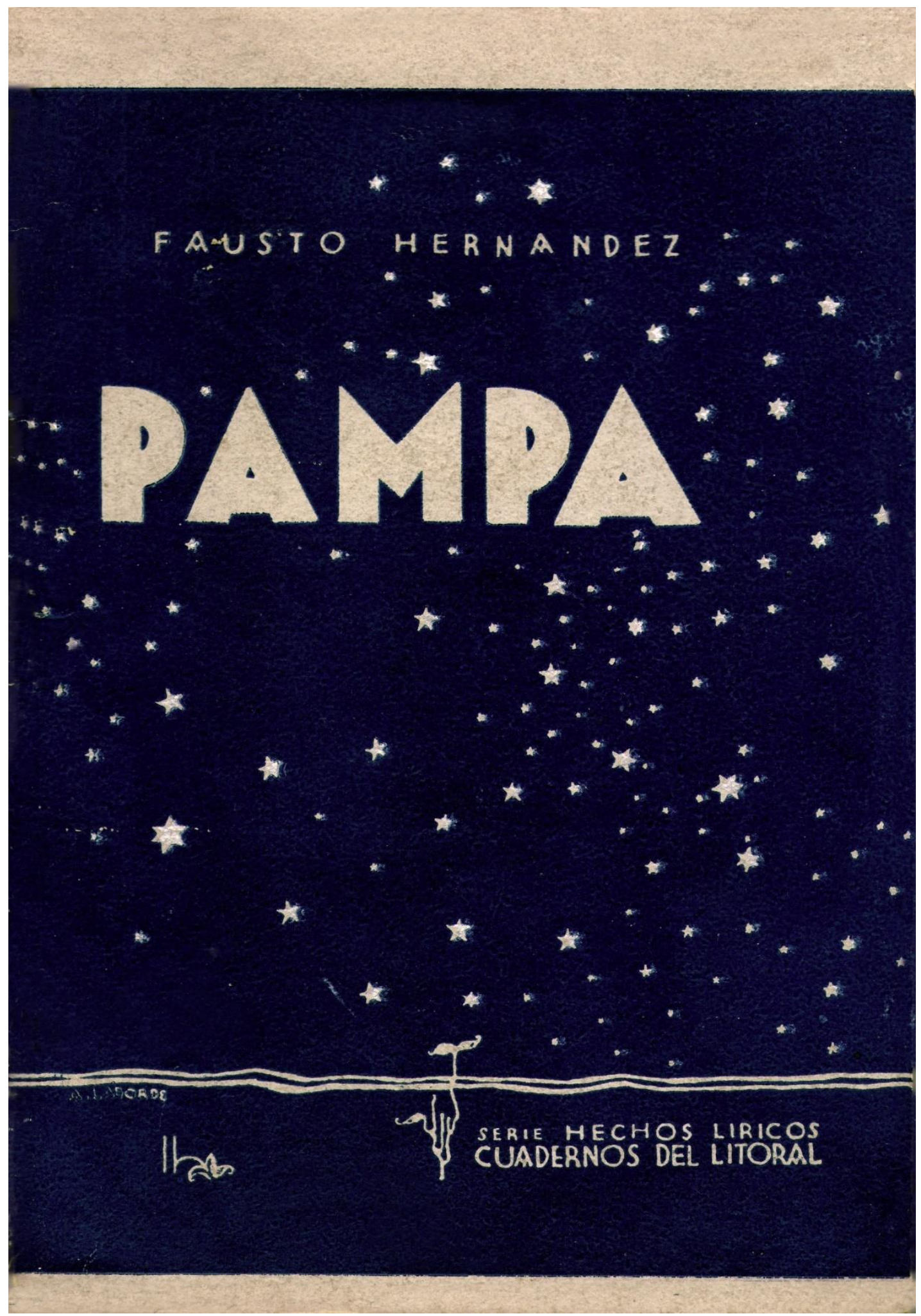


Figura 7. Ilustración de Ricardo Warecki para el texto de Luis María Albamonte, "El loco del callejón”. Boletín de Cultura Intelectual, II, núm. 13 (noviembre de 1939): 9-10.

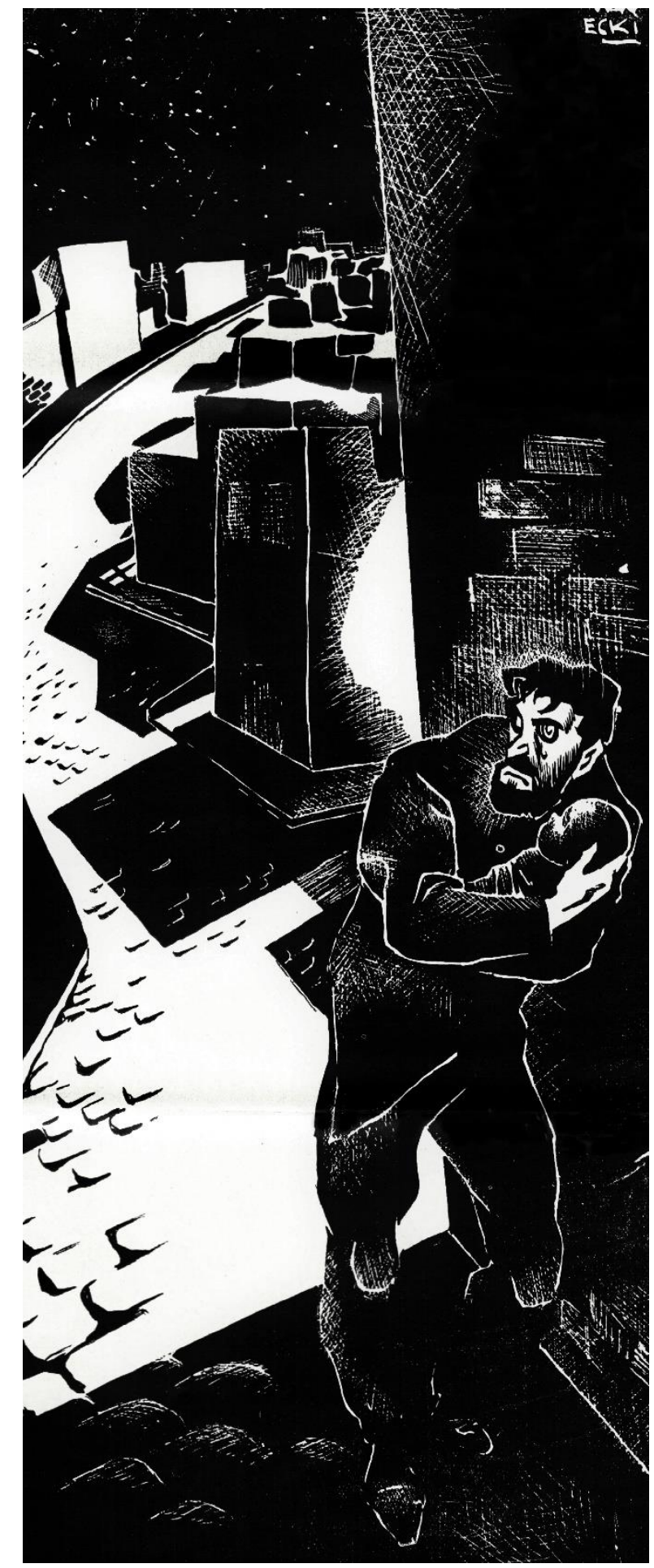




\section{en-claves}

Figura 8. Ilustración de Ricardo Warecki para el libro de Félix Molina Téllez, La ronda de los candiles. Poemas (Rosario, Ed. América: 1938).

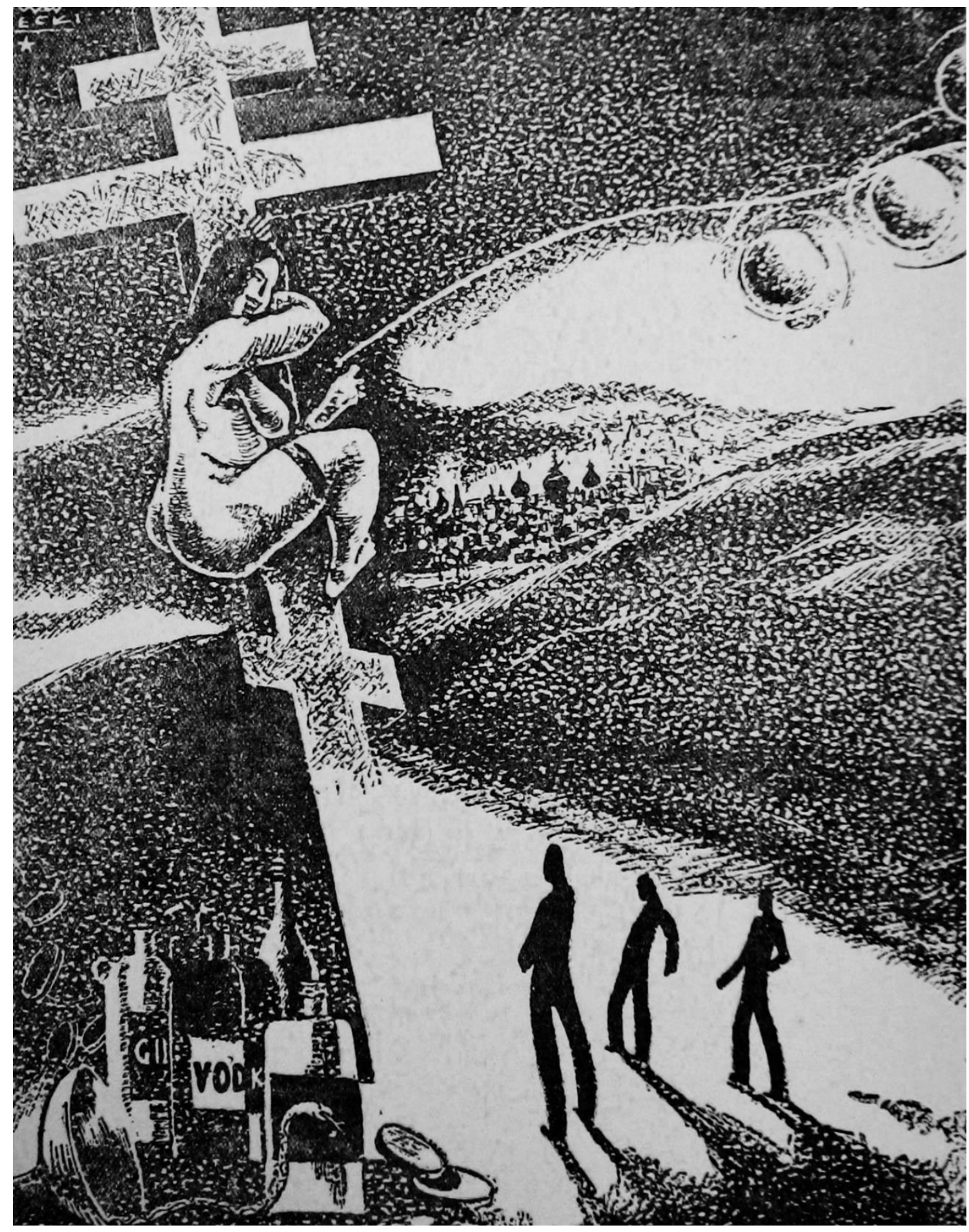


Figura 9. Ilustración de Ricardo Warecki para el texto de Agustín Zapata Gollán, "El príncipe Enrique”. Boletín de Cultura Intelectual, año II, núm. 19 (mayo de 1940): 75.

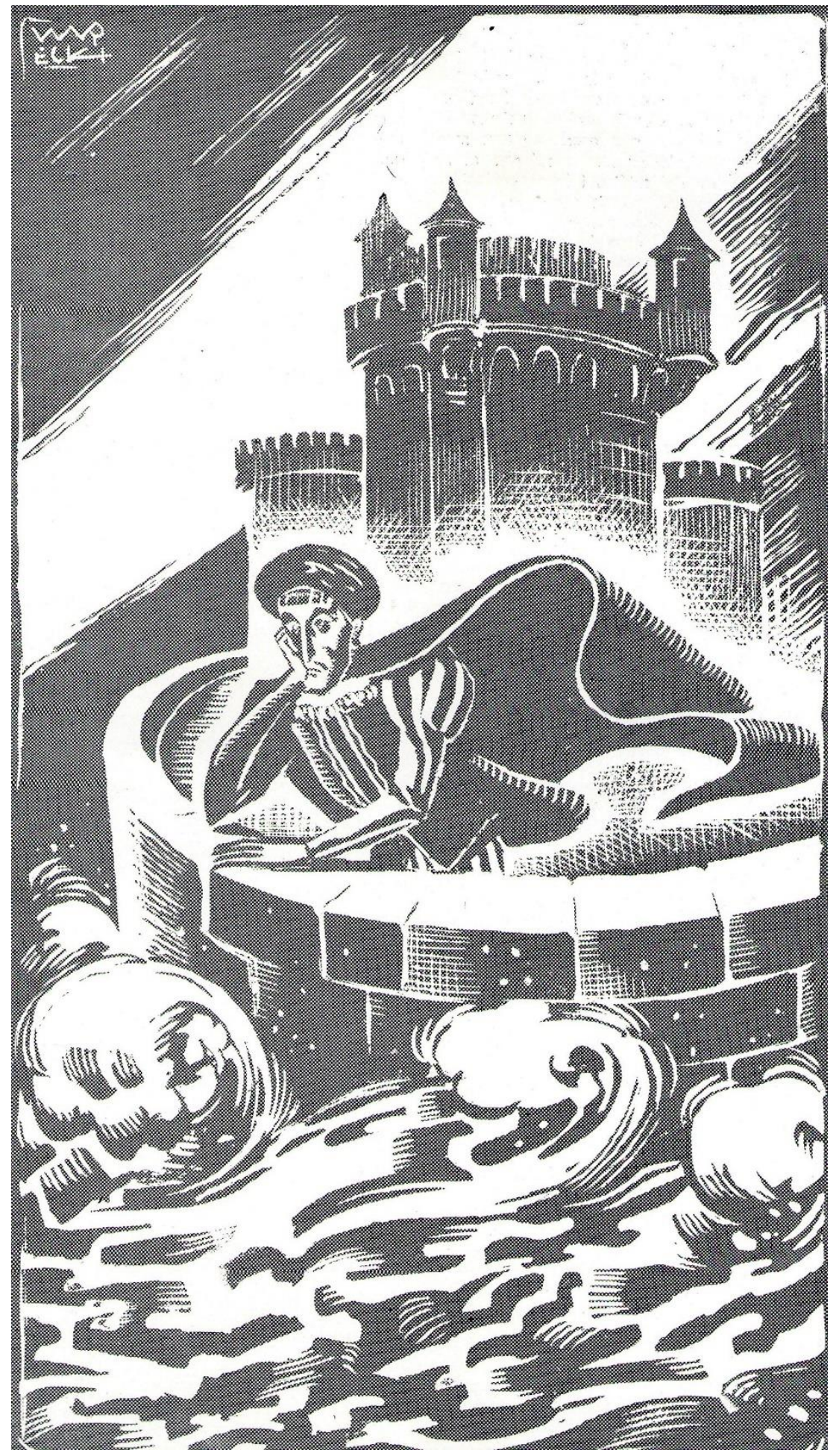


Figura 10. Publicidad de Ricardo Warecki para el Boletín de Cultura Intelectual, núm. 24 (octubre, 1943).

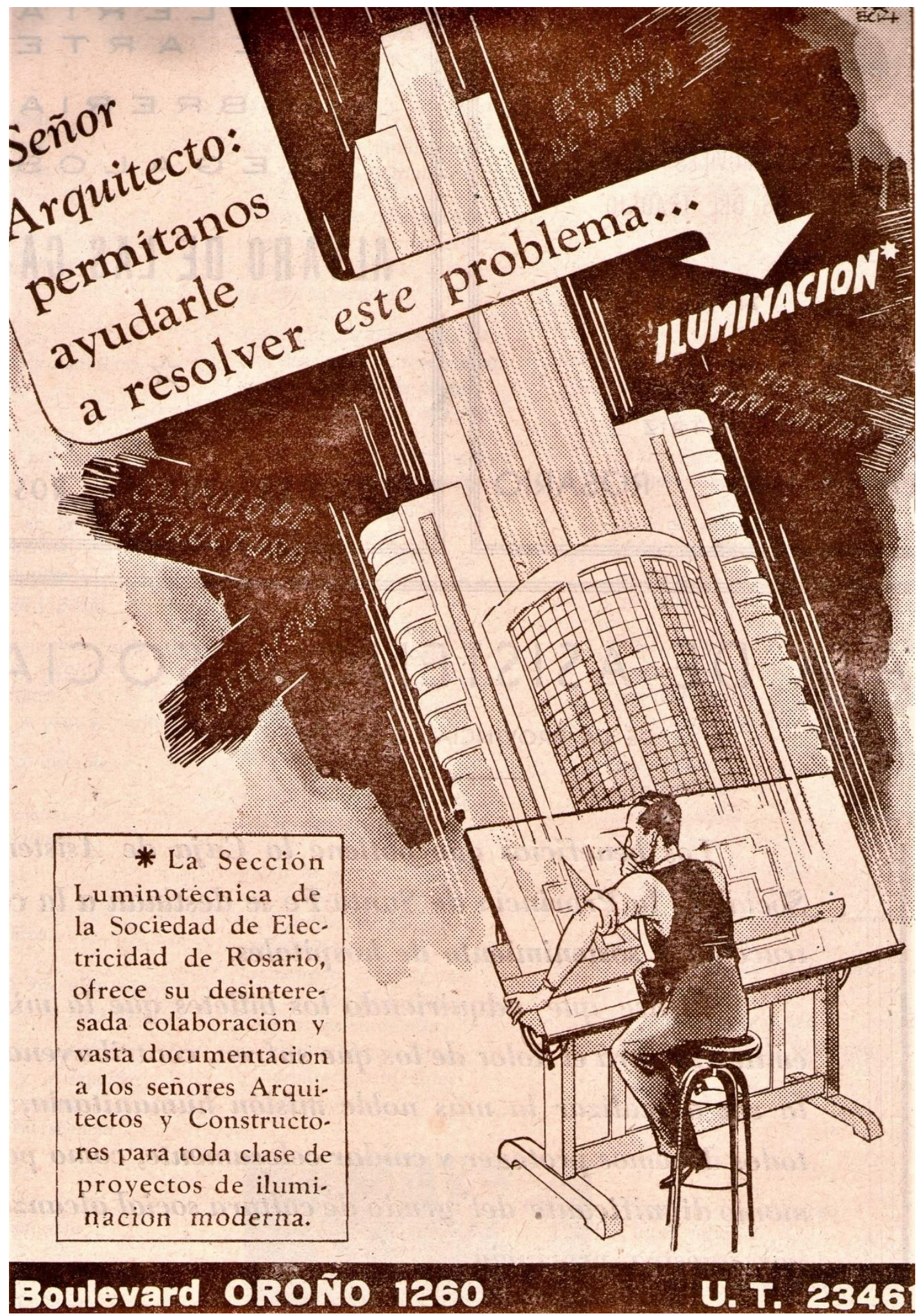


Figura 11. Ilustración de Ricardo Warecki para el índice de la revista Paraná (Rosario, 19411943).
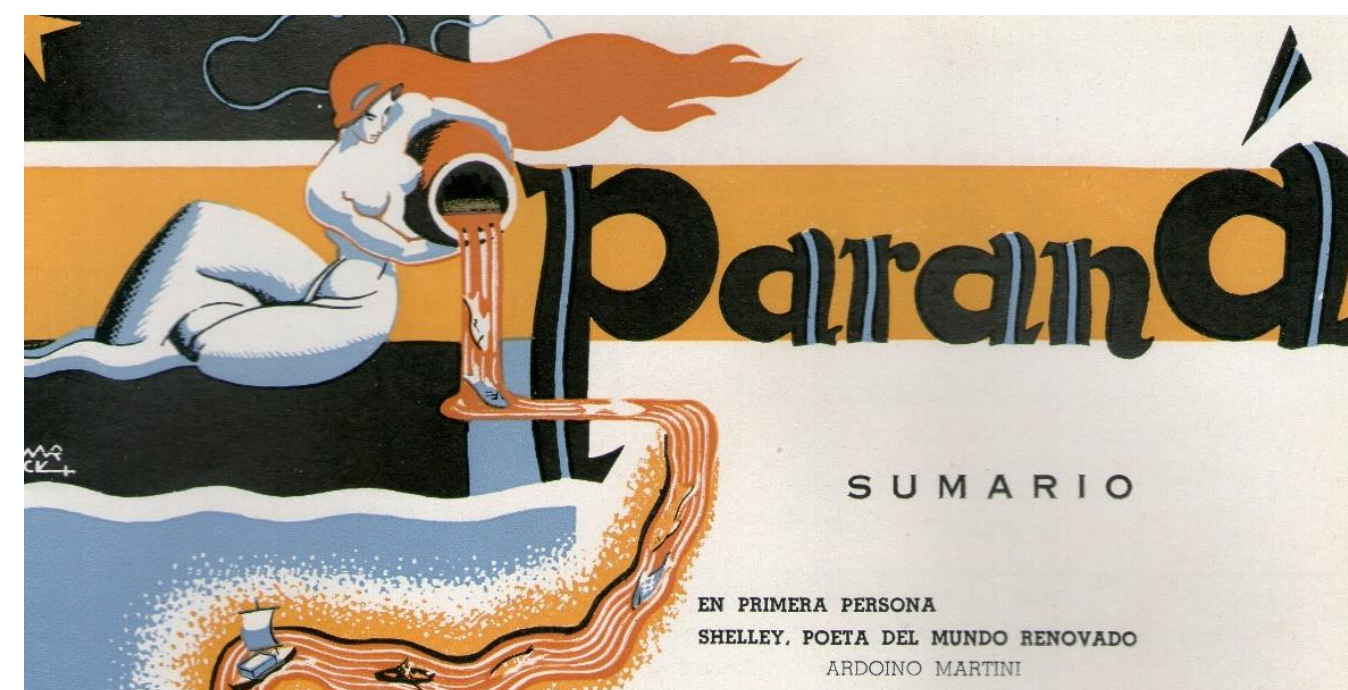

MI MAS FIRME VOCACION

PATRIA LITORAL
Yo te quiero alabar - Invocación y soneto a la voz terrígena - Soledad de la espiga - Soledad - Ala. banza del colono - Tiempo de hoy - El labrador que dejaba la tierra - Junto al río - Un día... - Crepúsculo CARLOS CARLINO

LA AUTOBIOGRAFIA

EL ESPECTADOR DE LA PRIMERA FILA ROSA WERNICKE

EL CAMINO DE MANUEL MUSTO R-E. MONTES i BRADLEY

¡DE QUÉ NOS PODEMOS ASUSTAR! TIERRA Y GENTE

Alas al viento - Camachui - Camambú - Miquichí - Doña Gabina la brava - Don Jeromito Díaz. contador de cuancho - Angeld Maria cumplio quince años - Yerbea. dora - El emparve - Peón de estancia - Soledad MARCELINO M. ROMAN

\section{CONATO DE AUTOBIOGRAFIA}

EN TORNO AL HOMBRE

L $\alpha$ intimidad - Nueva semblanza de Tartufo - Alacranería y chismorreo ALCIDES GRECA

MANUEL MUSTO -bronce- EDUARDO BARNES PERALITO EN FIESTA - GLADIOLOS ROSAS - MA ÑANA DE OTOÑO-óleOS- MANUEL MUSTO CON EL CATALEjo * ESPINEL - ESTAFETA DE A BORDO Ex-libris LEONIDAS GAMBARTES * Pórtico - Ardoino Martini - Marcelino M. Román - RICARDO WARECKI * Shelley cesar a. cakginNo " hulometra carlos carLinO "Rosa Wernicke - llustracion a "El espectador de la primera fila" - JULIO VANZO * Alcides Greca - ALFREDO LABORDE Viñetas

de CESAR CAGGIANO - CARLOS CARLINO - JULIO VANZO ENRIQUE ESTRADA BELLO - RICARDO WARECKI - RO LANDO DE MARCO - ALFREDO LABORDE I PEDRO HERMENEGILDO GIANZONE

Primavera 1941 - Litoral Argentino - Año 1 - Número 2 


\section{en-claves}

Figura 12. Ilustración de Ricardo Warecki para el texto de Luis María Albamonte, "La terrible mentira de Sámbur". Paraná, núm. 4-7 (1943): 15.

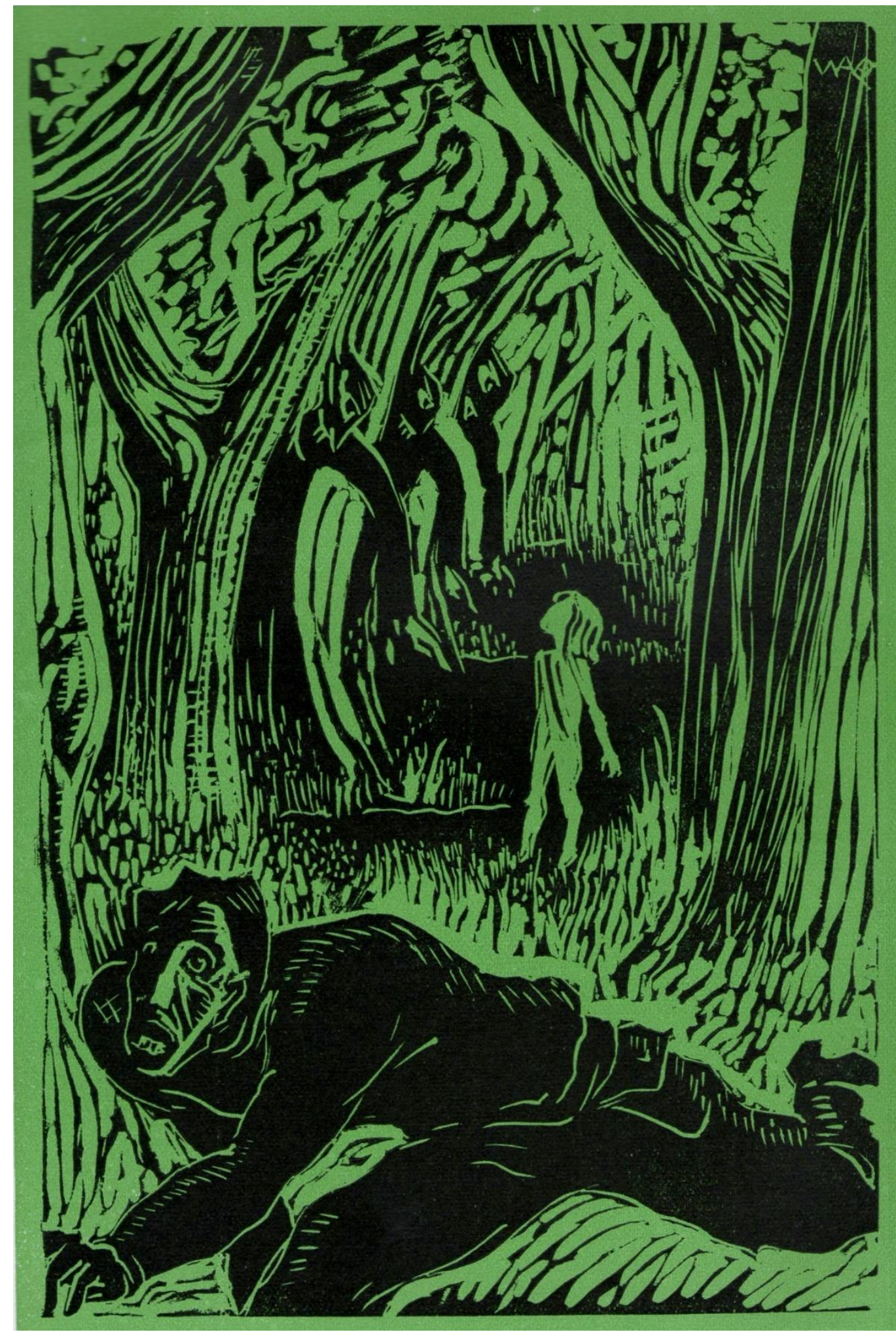


Figura 13. Ilustración de Ricardo Warecki para el texto de Ricardo Ernesto Montes i Bradley, “¿I ahora, Pedro?”. Paraná, núm. 1 (invierno de 1941): 113.

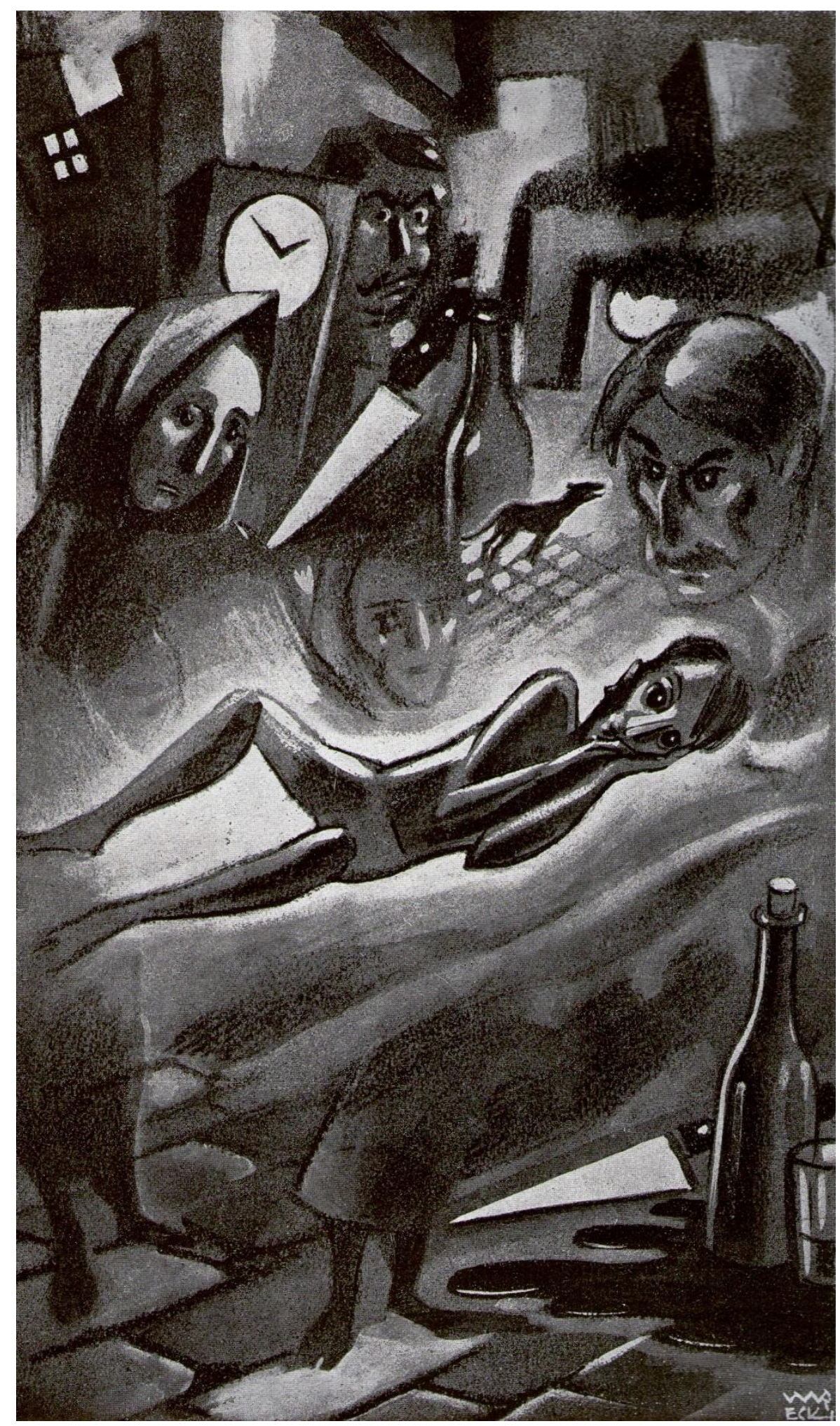


Figura 14. Ilustración de Ricardo Warecki para "Momentos de la muerte transparente", de Félix Molina Téllez. Paraná, núm. 4-7 (1943): 110.

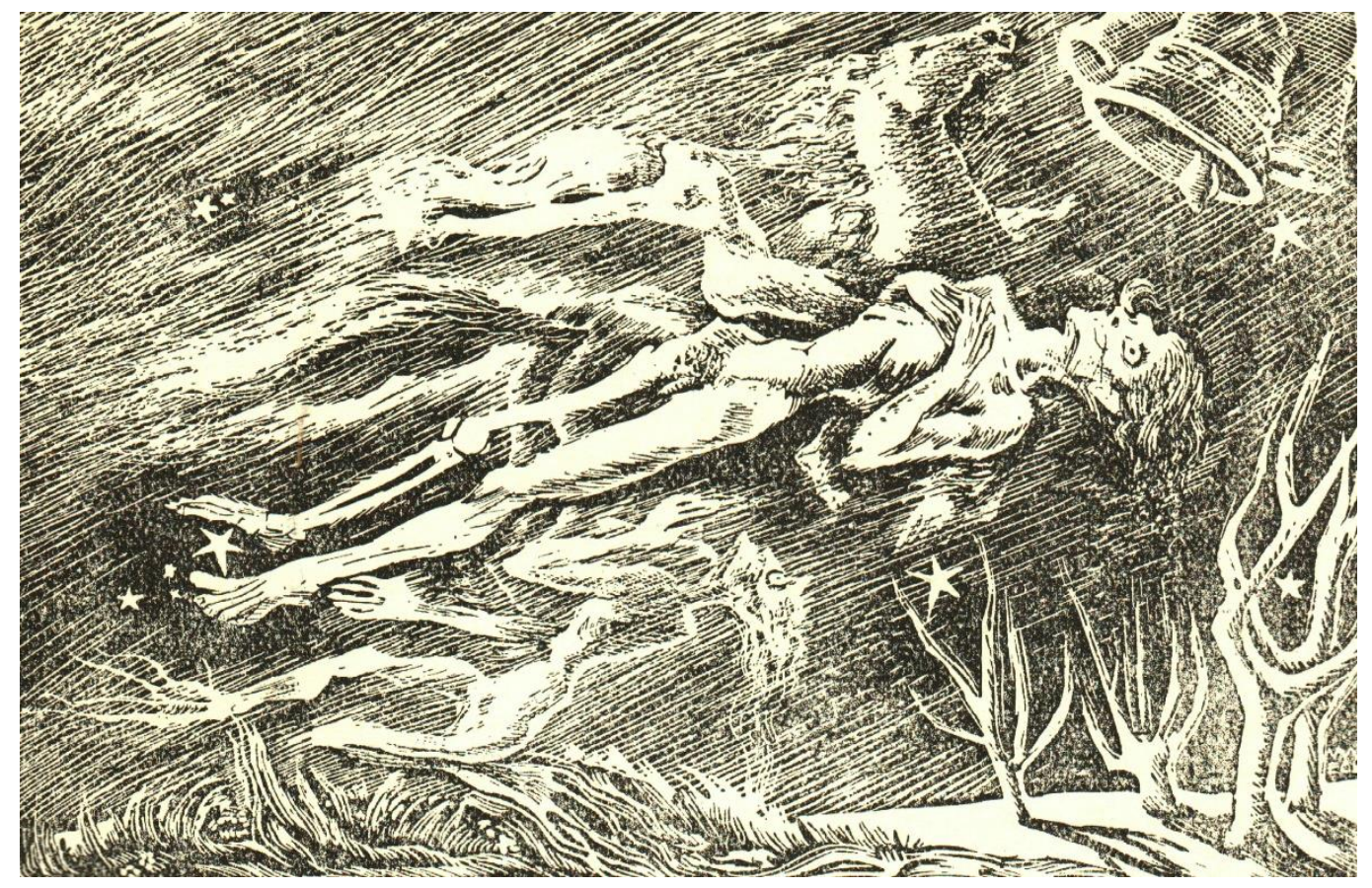

Figura 15. Ilustración de Ricardo Warecki para "Momentos de la muerte transparente", de Félix Molina Téllez. Paraná, núm. 4-7 (1943): 114.

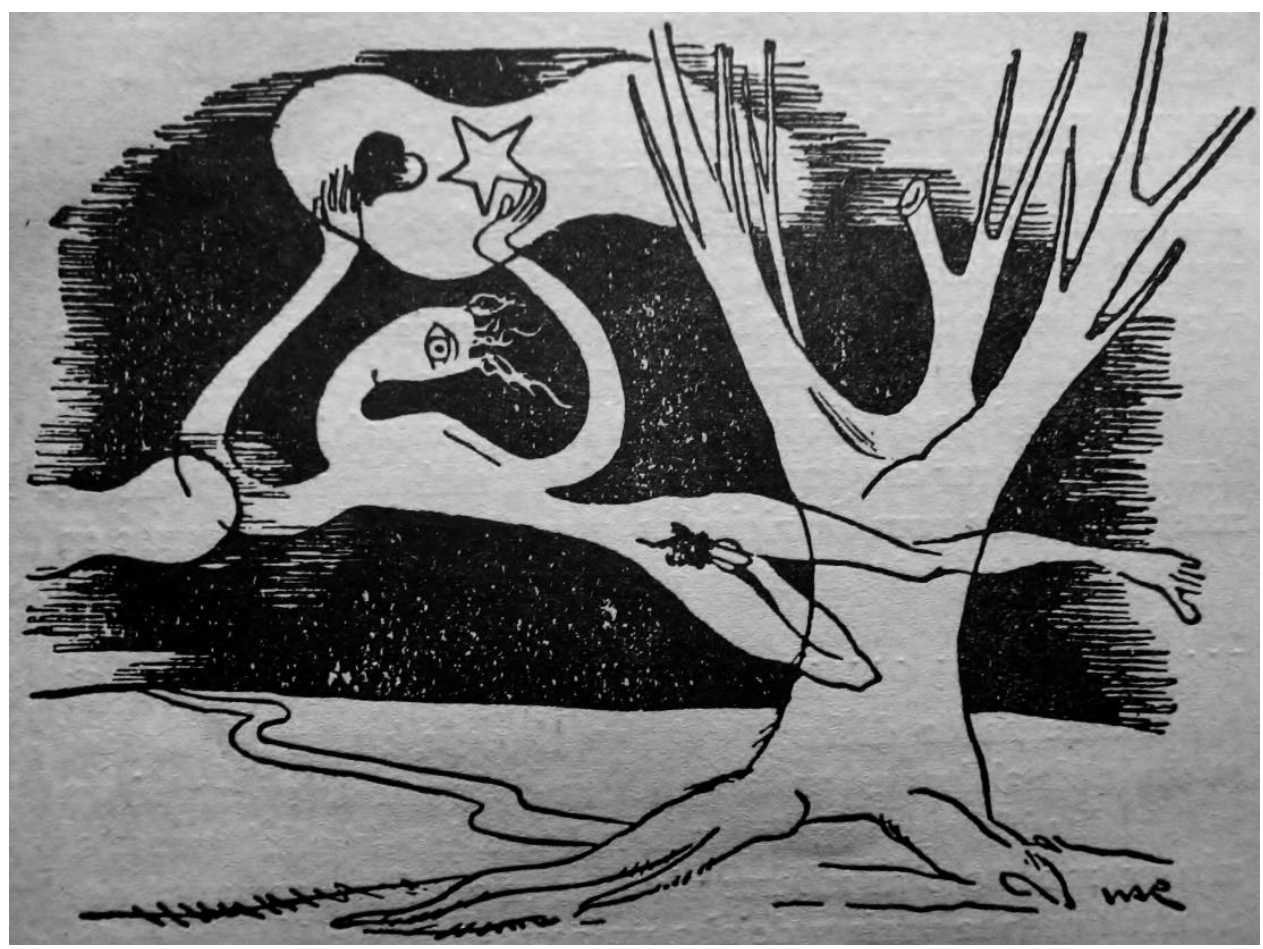


Figura 16. Ilustración de Ricardo Warecki para "Noches de verano", de Mateo Booz. Paraná, núm. 3 (verano de 1941): 291.

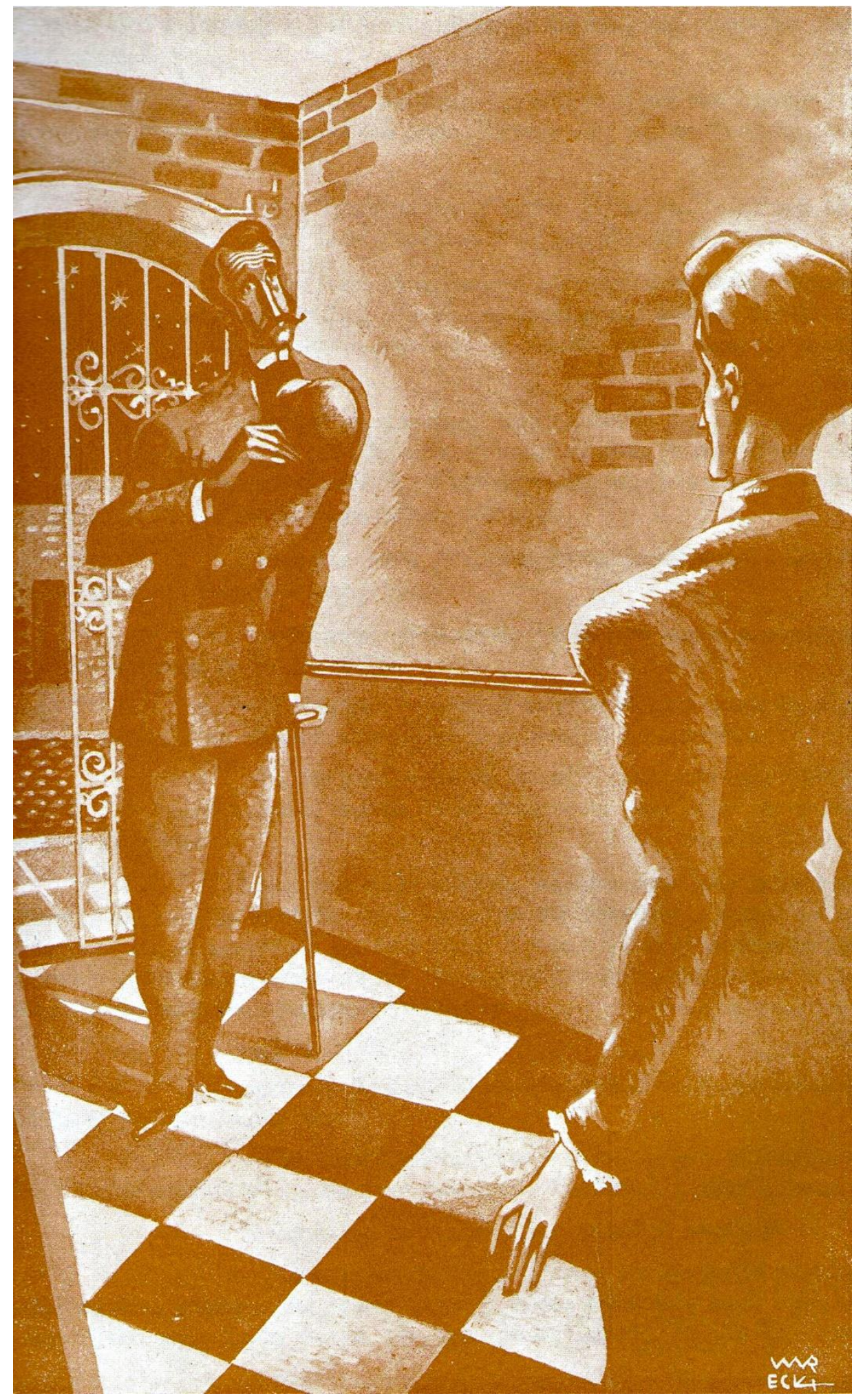


Figura 17. Ilustración de Ricardo Warecki para "Situación de Andrade", de Carlos María Onetti. Paraná, núm. 4-7 (1943): 95.

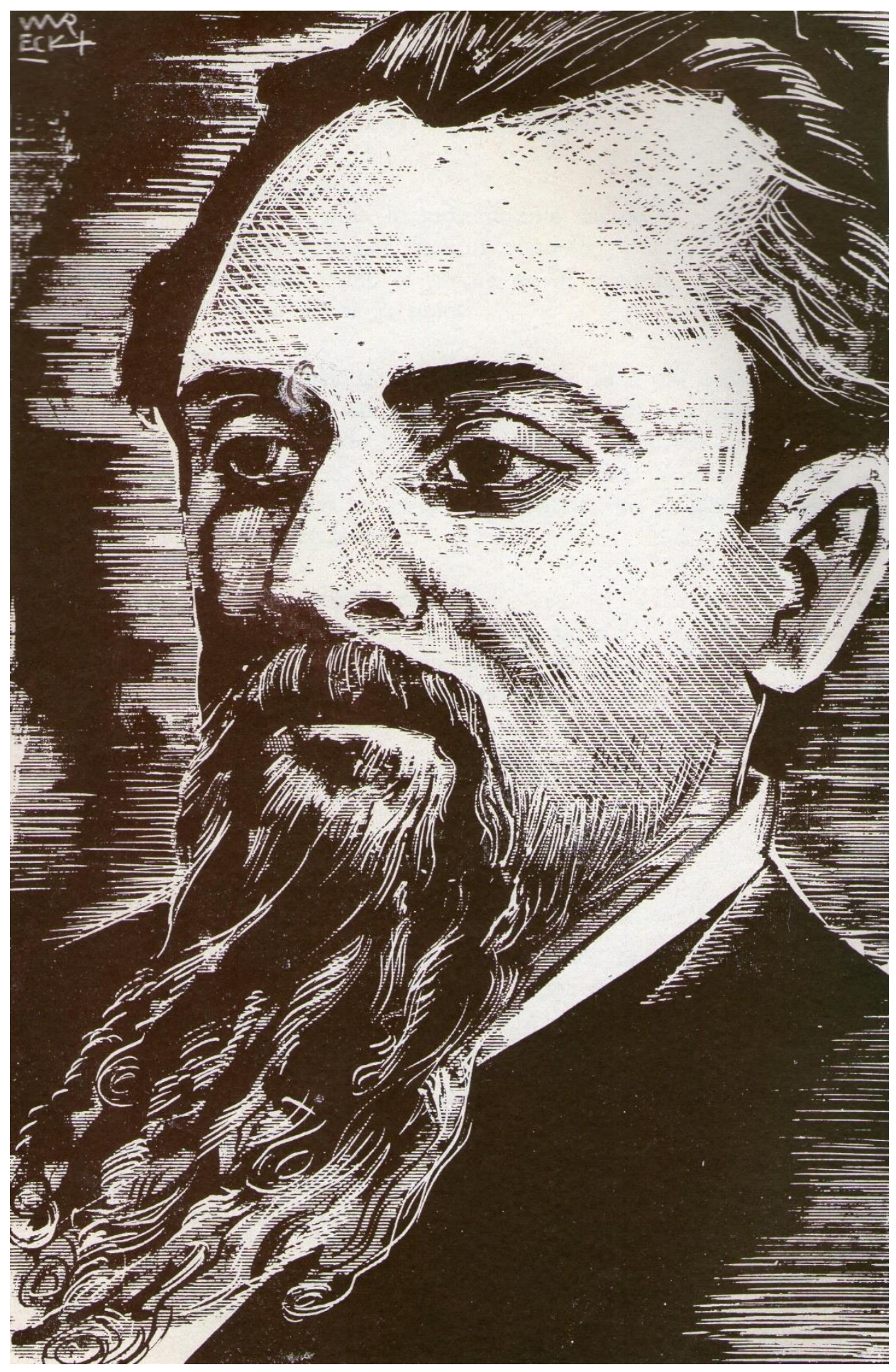

